\title{
EMP and SIMS studies on Mn/Ca and Fe/Ca systematics in benthic foraminifera from the Peruvian OMZ: a contribution to the identification of potential redox proxies and the impact of cleaning protocols
}

\author{
N. Glock ${ }^{1,2}$, A. Eisenhauer ${ }^{2}$, V. Liebetrau ${ }^{2}$, M. Wiedenbeck ${ }^{3}$, C. Hensen ${ }^{2}$, and G. Nehrke ${ }^{4}$ \\ ${ }^{1}$ Sonderforschungsbereich 754, Christian-Albrechts-University Kiel, Climate-Biogeochemistry Interactions in the Tropical \\ Ocean, Kiel, Germany \\ ${ }^{2}$ Helmholtz-Zentrum für Ozeanforschung Kiel, GEOMAR, Wischhofstr. 1-3, 24148 Kiel, Germany \\ ${ }^{3}$ Helmholtz-Zentrum Potsdam, GFZ German Research Centre for Geosciences, Telegrafenberg, 14473 Potsdam, Germany \\ ${ }^{4}$ Alfred Wegener Institut für Polar- und Meeresforschung, Am Handelshafen 12, 27570 Bremerhaven, Germany
}

Correspondence to: N. Glock (nglock@geomar.de)

Received: 3 August 2011 - Published in Biogeosciences Discuss.: 8 August 2011

Revised: 1 December 2011 - Accepted: 6 January 2012 - Published: 18 January 2012

\begin{abstract}
In this study we present an initial dataset of $\mathrm{Mn} / \mathrm{Ca}$ and $\mathrm{Fe} / \mathrm{Ca}$ ratios in tests of benthic foraminifera from the Peruvian oxygen minimum zone (OMZ) determined with SIMS. These results are a contribution to a better understanding of the proxy potential of these elemental ratios for ambient redox conditions. Foraminiferal tests are often contaminated by diagenetic coatings, like $\mathrm{Mn}$ rich carbonate- or $\mathrm{Fe}$ and $\mathrm{Mn}$ rich (oxyhydr)oxide coatings. Thus, it is substantial to assure that the cleaning protocols are efficient or that spots chosen for microanalyses are free of contaminants. Prior to the determination of the element/Ca ratios, the distributions of several elements $(\mathrm{Ca}, \mathrm{Mn}, \mathrm{Fe}, \mathrm{Mg}, \mathrm{Ba}, \mathrm{Al}, \mathrm{Si}, \mathrm{P}$ and $\mathrm{S}$ ) in tests of the shallow infaunal species Uvigerina peregrina and Bolivina spissa were mapped with an electron microprobe (EMP). To visualize the effects of cleaning protocols uncleaned and cleaned specimens were compared. The cleaning protocol included an oxidative cleaning step. An Fe rich phase was found on the inner test surface of uncleaned $U$. peregrina specimens. This phase was also enriched in $\mathrm{Al}$, $\mathrm{Si}, \mathrm{P}$ and $\mathrm{S}$. A similar Fe rich phase was found at the inner test surface of B. spissa. Specimens of both species treated with oxidative cleaning show the absence of this phase. Neither in B. spissa nor in U. peregrina were any hints found for diagenetic (oxyhydr)oxide or carbonate coatings. $\mathrm{Mn} / \mathrm{Ca}$ and $\mathrm{Fe} / \mathrm{Ca}$ ratios of single specimens of $B$. spissa from different locations have been determined by secondary ion mass spectrometry (SIMS). Bulk analyses using solution ICP-MS
\end{abstract}

of several samples were compared to the SIMS data. The difference between SIMS analyses and ICP-MS bulk analyses from the same sampling sites was $14.0-134.8 \mu \mathrm{mol} \mathrm{mol}^{-1}$ for the $\mathrm{Fe} / \mathrm{Ca}$ and $1.68( \pm 0.41) \mu \mathrm{mol} \mathrm{mol}^{-1}$ for the $\mathrm{Mn} / \mathrm{Ca}$ ratios. This is in the same order of magnitude as the variability inside single specimens determined with SIMS at these sampling sites $\left(1 \sigma_{[\mathrm{Mn} / \mathrm{Ca}]}=0.35-2.07 \mu \mathrm{mol} \mathrm{mol}^{-1} ; 1 \sigma_{[\mathrm{Fe} / \mathrm{Ca}]}=\right.$ 93.9-188.4 $\mu \mathrm{mol} \mathrm{mol}^{-1}$ ). The $\mathrm{Mn} / \mathrm{Ca}$ ratios in the calcite were generally relatively low $\left(2.21-9.93 \mu \mathrm{mol} \mathrm{mol}^{-1}\right)$ but in the same magnitude and proportional to the surrounding pore waters $\left(1.37-6.67 \mu \mathrm{mol} \mathrm{mol}^{-1}\right)$. However, the $\mathrm{Fe} / \mathrm{Ca}$ ratios in B. spissa show a negative correlation to the concentrations in the surrounding pore waters. Lowest foraminiferal $\mathrm{Fe} / \mathrm{Ca}$ ratios $\left(87.0-101.0 \mu \mathrm{mol} \mathrm{mol}^{-1}\right)$ were found at $465 \mathrm{~m}$ water depth, a location with a strong sharp Fe peak in the pore water next to the sediment surface and respectively, high $\mathrm{Fe}$ concentrations in the surrounding pore waters. Previous studies found no living specimens of $B$. spissa at this location. All these facts hint that the analysed specimens already were dead before the Fe flux started and the sampling site just recently turned anoxic due to fluctuations of the lower boundary of the $\mathrm{OMZ}$ near the sampling site ( $465 \mathrm{~m}$ water depth). Summarized $\mathrm{Mn} / \mathrm{Ca}$ and $\mathrm{Fe} / \mathrm{Ca}$ ratios are potential proxies for redox conditions, if cleaning protocols are carefully applied. The data presented here may be rated as base for the still pending detailed calibration. 


\section{Introduction}

Various element to $\mathrm{Ca}$ ratios in foraminiferal calcite have been widely used to reconstruct chemical or physical properties in the ancient ocean. A well established approach is the temperature reconstruction using the $\mathrm{Mg} / \mathrm{Ca}$ ratio (Nürnberg et al., 1996; Rosenthal et al., 1997; Hastings et al., 1998; Lea et al., 1999; Elderfield and Ganssen, 2000; Lear et al., 2002). But other proxies are utilized too like the $\mathrm{U} / \mathrm{Ca}$ ratio for redox state and $\mathrm{CO}_{3}^{2-}$ tracing (Russel et al., 1994, 2004; Yu et al., 2008), $\mathrm{Zn} / \mathrm{Ca}$ ratios for carbonate saturation (Marchitto et al., 2000) and Cd/Ca ratios as phosphate proxy (Boyle and Keigwin, 1985; Boyle, 1988; Bertram et al., 1995, Came et al., 2003). Recently boron isotopes in foraminiferal calcite became an important proxy for $\mathrm{pH}$ reconstruction (Spivack et al., 1993; Sanyal et al., 1995; Palmer et al. 1998; Pearson and Palmer, 2000; Sanyal et al., 2001; Palmer and Pearson, 2003; Ni et al., 2007; Foster, 2008; Kasemann et al., 2009; RollionBard and Erez, 2010; Rae et al., 2011). The V/Ca ratio has been suggested as a proxy for redox-conditions (Hastings et al., 1996a, b and c) while the $\mathrm{Ba} / \mathrm{Ca}$ ratio has been shown to record seawater compositions (Lea and Boyle, 1991; Lea and Spero, 1992, 1994). Ba/Ca ratios have already been used to trace deglacial meltwater in deep and intermediate water masses (Lea and Boyle, 1989, 1990a and b; Martin and Lea, 1998; Hall and Chan, 2004a, b).

Fossil foraminiferal tests often show diagenetic coatings which strongly influence the measured element/Ca ratios and thus rigorous cleaning techniques have to be deployed. About three decades ago, a procedure was developed to remove these contaminants by rinsing crushed tests with distilled water/methanol to remove adhesive clays followed by a reductive cleaning step to remove metal oxide coatings (Boyle, 1981). Later an additional oxidative cleaning step was added to get rid of organic contaminations (Boyle and Keigwin, 1985). The influence of the different cleaning steps on the $\mathrm{Mg} / \mathrm{Ca}$ ratios has been tested and it has been shown that the clay removal step is the most important one while the reductive cleaning step produces a decrease of about $10-15 \%$ on the $\mathrm{Mg} / \mathrm{Ca}$ ratios (Barker et al., 2003). Different cleaning techniques and their influence on eight elemental/Ca ratios have also been investigated by $\mathrm{Yu}$ et al. (2007). Also there have been experiments of cleaning by using a flow-through system with automated chromatographic equipment (Haley and Klinkhammer, 2002; Haley et al., 2005). In such a flow through system, contaminants are chemically removed from the tests and then the cleaned calcite is dissolved in a stream of weak acid. The advantage of this method is that the different fractions could be collected separately and the measurements of contamination tracers like Fe could show in which fractions only clean dissolved foraminiferal calcite is collected. Furthermore the flowthrough system could minimize the problem of re-adsorption of rare-earth-elements. Diagenetic contaminant phases like Mn carbonates as well as $\mathrm{Mn}$ and Fe rich oxyhydroxides have been identified with laser-ablation-ICP-MS (LA-ICPMS) and electron microprobe (EMP) mapping (Pena et al., 2005, 2008). $\mathrm{Mn} / \mathrm{Ca}$ and $\mathrm{Fe} / \mathrm{Ca}$ ratios therefore have often been used as indicators for diagenetic overprint of the samples. Nevertheless the studies disagree what is considered an acceptable level of test $\mathrm{Mn} / \mathrm{Ca}$ from $50 \mu \mathrm{mol} \mathrm{mol}^{-1}$ to > $150 \mu \mathrm{mol} \mathrm{mol}^{-1}$ (Boyle, 1983; Boyle and Keigwin, 1985, 1986; Delaney, 1990; Ohkouchi et al., 1994; Lea, 2003). Without diagenetic coatings, the $\mathrm{Mn} / \mathrm{Ca}$ ratio in Hoeglundina elegans has been used to trace suboxic conditions during sapropel formation (Fhlaitheartha et al., 2010). Also living stained specimens of $H$. Elegans from the oxygen minimum zone at the Arabian Sea show an increase of the $\mathrm{Mn} / \mathrm{Ca}$ ratio at the lower boundary of the oxygen minimum zone (Reichart et al., 2003). Culture experiments on Ammonia tepida showed that $\mathrm{Mn}$ is incorporated into the test recording the Mn concentration in the ambient water (Munsel et al., 2010).

Several analytical techniques have been employed for analyses of element/Ca ratios or isotope systems in foraminiferal calcite. Techniques for multi-element analyses using only small sample volumes have been developed on sector field ICP-MS (Marchitto, 2006) and quadrupole ICP-MS (Yu et al., 2005; Harding et al., 2006). Microanalytic methods also allow analysing single specimens locally. The advantage of the EMP is that single foraminiferal tests can be analysed with comparable low damage at the surface after preparation of polished sections. These sections can be remeasured after renewed grinding and polishing. This is an important prerequisite for comparison with other low trace methods like secondary ion mass spectrometry (SIMS). Both elemental mapping by means of EMP and spot analyses of test calcite can help identify contaminant coatings and can characterise the distributions of trace elements inside the foraminiferal calcite, improving the usability of element to $\mathrm{Ca}$ ratios as paleoenvironmental proxies (Nürnberg, 1995; Nürnberg et al., 1996; Eggins et al., 2003, 2004; Sadekov, 2005; Toyofoko and Kitazato, 2005; Pena et al., 2008). Also laser ablation techniques on single foraminifera have been used in the recent past in order to determine several element/Ca ratios (Wu and Hillaire-Marcel, 1995; Hathorne et al., 2003; Reichart et al., 2003; Pena, 2005; Munsel et al., 2010).

Another valuable tool for foraminiferal microanalyses is the SIMS. With good sample preservation after analysis in the same way as the EMP, SIMS has been used to produce element mappings and determine element/Ca ratios in foraminiferal calcite (Allison and Austin, 2003; Sano et al., 2005; Bice et al., 2005; Kunioka et al., 2006). It has also been used to analyse $\delta^{11} \mathrm{~B}$ in single foraminifera (Kasemann et al., 2008; Rollion-Bard and Erez, 2009) and the intratest variability of $\delta^{18} \mathrm{O}$ (Rollion-Bard et al., 2008). Other powerful, though less widely available techniques like particle induced x-ray emission (Gehlen et al., 2004) or $\mu$ synchroton XRF (Munsel et al., 2010) have also been empolyed in foraminifera studies. Microanalytical methods are 
favourable when there is only a very limited number of specimens available or when an assessment of chemical heterogeneity is required.

This study focuses mainly on the elements Mn and Fe. Both elements are strongly redox sensitive and thus potential proxies for redox-conditions. Mn and Fe oxides are used as an electron acceptor when the energetically more favorable oxidants are depleted (Bender and Heggie, 1984; Granina et al., 2004). $\mathrm{Mn} / \mathrm{Fe}$ ratios in lake sediments for example are commonly used as paleoproxy for redox-conditions (Wersin et al., 1991). However, the strong sensitivity of $\mathrm{Mn}$ and $\mathrm{Fe}$ oxides in sediments to early diagenesis might erase any signal in periods when oxygen is strongly depleted in the Peruvian OMZ. Mn and Fe bound in calcitic tests of benthic foraminifera might be more stable against influences of early diagenesis. Nevertheless, due to the strong influence of contamination with $\mathrm{Mn}$ rich carbonate or $\mathrm{Mn}$ and Fe rich (oxyhydr)oxide coatings on the $\mathrm{Mn} / \mathrm{Ca}$ and $\mathrm{Fe} / \mathrm{Ca}$ ratios, sufficient cleaning is important to assure the measurement of the lattice bound signal. Here we present an initial study about $\mathrm{Mn} / \mathrm{Ca}$ and $\mathrm{Fe} / \mathrm{Ca}$ ratios in benthic foraminifera from the Peruvian OMZ with SIMS and comparison to ICP-MS data. SIMS is favourable for this approach because it is possible to measure the elemental ratios directly inside the test walls of cross-sections while contaminating coatings are usually located on the inner and outer wall surfaces.

For the analyses we used the shallow infaunal benthic species Bolivina spissa and Uvigerina peregrina from the Peruvian OMZ. Besides the Peruvian OMZ B. spissa can be found in several preferential suboxic habitats along the Pacific continental margin. The presence of $B$. spissa has been documented in the West Pacific at cold-seep environments off Costa Rica (Heinz et al., 2008), the Californian borderlands (Lutze, 1962; Silva et al., 1996) and Monterey Bay cold-seeps (Bernhard et al., 2001) as well as in the East Pacific at the Cascadia convergent margin (Heinz et al., 2005) and Sagami Bay, Japan (Nomaki et al., 2006; Glud et al., 2009). B. spissa selectively ingests certain types of phytodetritus precipitated from the surface waters, indicating that its live cycle is related to phytoplankton blooms (Nomaki et al., 2006; Glock et al., 2011). U. peregrina in fact is more globally distributed. It has been reported in European waters like the Mediterranean Sea or the United Kingdom Exclusive Economic Zone (Gross, 2001), as well as in the Gulf of Mexico (Sen-Gupta et al., 2009) and Monterey Bay cold-seeps (Bernhard et al., 2001). U. peregrina also tends to prefer oxygen depleted environments like OMZs, cold seeps, hydrothermal vents and whale carcasses (Baker et al., 2010). The Uvigerina genus in general is known as an indicator for high productivity and appeared in higher abundance and size coincidently with the increase of organic carbon content in the sediments downcore in the Eastern Equatorial Pacific (Pedersen et al., 1988). Ultrastructural observations showed evidence for deposit feeding on organic detritus in $U$. peregrina (Goldstein and Corliss, 1994). This would explain its close correlation to the abundance of organic matter in the sediments.

Due to the possible contaminants outlined above it is substantial to assure that the cleaning protocols are efficient or that spots chosen for microanalyses are free of contaminants. Thus, prior to the determination of $\mathrm{Mn} / \mathrm{Ca}$ and $\mathrm{Fe} / \mathrm{Ca}$ ratios, cross-sections of $U$. peregrina and $B$. spissa from the Peruvian OMZ were analysed for contaminating coatings with elemental EMP mapping. Cleaned and uncleaned specimens are compared to visually demonstrate the effect of cleaning. After these preanalyses Bolivina spissa is used for the determination of $\mathrm{Fe} / \mathrm{Ca}$ and $\mathrm{Mn} / \mathrm{Ca}$ ratios on SIMS and ICP$\mathrm{MS}$, and these ratios are compared to pore water data. Because of the relative widespread distribution among the Peruvian OMZ, B. spissa was available from habitats with a wide range of chemical conditions. Nevertheless, the number of the specimens was strongly limited at some sampling sites which was another reason for using SIMS. If enough specimens were available for bulk analysis in a sample, SIMS was compared to ICP-MS data. Studies on the pore density in B. spissa showed a morphological adaptation of the test to different environmental conditions (Glock et al., 2011) which makes this species favourable for elemental analyses, too.

\section{Material and methods}

\subsection{Sampling procedure}

Six short $(12-26 \mathrm{~cm})$ sediment cores from the Peruvian OMZ were considered for the present study (Table 1). The cores were recovered by using multicore technology during R/V Meteor cruise M77/1 in October and November 2008. Immediately after the multicorer came on deck, one tube was chosen from the array, and brought to a laboratory at a constant room temperature of $4{ }^{\circ} \mathrm{C}$. Supernatant water of the core was carefully removed. Then the core was gently pushed out of the multicorer tube and cut into 10-mm-thick slices for benthic foraminiferal analysis. The samples were transferred to Whirl-Pak ${ }^{\mathrm{TM}}$ plastic bags and transported at a temperature of $4{ }^{\circ} \mathrm{C}$. One core was completely frozen, and later sliced and sub-sampled at GEOMAR, Kiel.

\subsection{Foraminiferal studies}

The surface sediments in the top centimeter were washed over a $63 \mu \mathrm{m}$ mesh sieve. The residues were collected in ethanol to prevent samples from dissolution and dried at $50^{\circ} \mathrm{C}$. They were further subdivided into the grain-size fractions of $63-125,125-250,250-315,315-355,355-400$, and $>400 \mu \mathrm{m}$. Specimens of the shallow infaunal species B. spissa for ICP-MS and SIMS analysis were picked from the $125-250 \mu \mathrm{m}$ fraction, specimens of Uvigerina peregrina for the microprobe analyses were picked from the 355$400 \mu \mathrm{m}$ fraction. 
Table 1. Sampling sites. $\left[\mathrm{O}_{2}\right]_{\mathrm{BW}}$ taken from Glock et al. (2011).

\begin{tabular}{lllll}
\hline Site & Longitude $(\mathrm{W})$ & Latitude $(\mathrm{S})$ & Water depth $(\mathrm{m})$ & {$\left[\mathrm{O}_{2}\right]_{\mathrm{BW}}\left(\mu \mathrm{mol} 1^{-1}\right)$} \\
\hline M77/1-421/MUC-13 & $75^{\circ} 34.82^{\prime}$ & $15^{\circ} 11.38^{\prime}$ & 519 & - \\
M77/1-455/MUC-21 & $78^{\circ} 19.23^{\prime}$ & $11^{\circ} 00.00^{\prime}$ & 465 & 2.42 \\
M77/1-487/MUC-39 & $78^{\circ} 23.17^{\prime}$ & $11^{\circ} 00.00^{\prime}$ & 579 & 3.7 \\
M77/1-565/MUC-60 & $78^{\circ} 21.40^{\prime}$ & $11^{\circ} 08.00^{\prime}$ & 640 & 8.17 \\
M77/1-604/MUC-74 & $78^{\circ} 22.42^{\prime}$ & $11^{\circ} 17.96^{\prime}$ & 878 & 34.23 \\
M77/1-445/MUC-15 & $78^{\circ} 30.02^{\prime}$ & $11^{\circ} 00.00^{\prime}$ & 928 & 36.77 \\
\hline
\end{tabular}

The samples were not stained with rose bengal or celltracker green. The sedimentation rates in this area range from $0.20-0.81 \mathrm{~mm} \mathrm{yr}^{-1}$. The benthic macrofauna consists mainly out of animals living on the sediment surface (e.g. gastropods, poriferans, tunicates, etc.) (Mosch et al., 2012). Thus, the bioturbation in this area is only limited to the surface sediments. We assume maximal sediment ages of the top cm of 12-50 yr. Since crustaceans were observed in water depth from $640 \mathrm{~m}$ and $740 \mathrm{~m}$ creating large holes with diameters up to $2.5 \mathrm{~cm}$ (Mosch et al., 2012) it might be that the bioturbation was stronger at station M77/1-565/MUC-60 (640 m).

\subsection{Cleaning methods}

For each ICP-MS analysis a bulk sample of 40 specimens of $B$. spissa was used. The tests were gently crushed between two glass plates. The test fragments were transferred into $\mathrm{PE}$ vials and rinsed three times with reverse osmosis water (ROW) having a conductivity of $0.055 \mu \mathrm{S} \mathrm{cm}^{-1}$ (Elga $^{\mathrm{TM}}$ PURELAB Ultra). After each rinsing step the vials were put into a supersonic bath for $20 \mathrm{~s}$. Afterwards the vials were rinsed three times with methanol and put into the supersonic bath for $1 \mathrm{~min}$ after each rinsing step. The vials were rinsed again two times with ROW to remove residual methanol. An oxidative reagent was freshly mixed by adding $100 \mu \mathrm{l}$ $30 \% \mathrm{H}_{2} \mathrm{O}_{2}$ to $10 \mathrm{ml}$ of a $0.1 \mathrm{M} \mathrm{NaOH}$ (p.a., Roth ${ }^{\mathrm{TM}}$ ) solution. Subsequently $350 \mu$ of this reagent were added to each vial. The vials were put into a waterbath at $92^{\circ} \mathrm{C}$ for 20 min. After another $20 \mathrm{~s}$ in the supersonic bath the vials were rinsed two times with ROW to remove residues of the oxidative reagent. The test fragments were transferred into clean vials with a pipette. Into each vial $250 \mu \mathrm{l} 0.001 \mathrm{M} \mathrm{HNO}_{3}$ (suprapure, Roth $^{\mathrm{TM}}$ ) were added. The vials were put into the supersonic bath for $20 \mathrm{~s}$. The extremely low acidic solution was removed and the vials were rinsed three times with ROW. The samples were dissolved in $300 \mu \mathrm{l} 0.075 \mathrm{M} \mathrm{HNO}_{3}$ (suprapure, Roth ${ }^{\mathrm{TM}}$ ), centrifuged and transferred into clean vials. Due to the risk of elevated Mn blanks the vials were replaced by Teflon beakers for $\mathrm{Mn}$ analyses (except for the cleaning step with $0.001 \mathrm{M} \mathrm{HNO}_{3}$ (suprapure, Merck ${ }^{\mathrm{TM}}$ ), the sample dissolution and the centrifugation).
The cleaning protocols for the microanalyses was in general the same with a few exceptions. The specimens were not crushed and one vial was used for one single specimen. The first three rinsing steps with ROW were skipped because specimens often lifted to the surface and got lost during the rinsing steps. The specimens were not transferred into a clean vial after the oxidative cleaning step and were not dissolved. After the last cleaning step the specimens were individual collected over a $125 \mu \mathrm{m}$ mesh stainless steel sieve.

\subsection{SIMS and EMP analyses}

\subsubsection{Oka calcite grain}

A matrix matched reference material was required in order to quantify SIMS trace element analyses. Using a New Wave Research $^{\mathrm{TM}}$ micromill a square having a $400 \mu \mathrm{m}$ and $200 \mu \mathrm{m}$ thickness was extracted from a calcite crystal from the OKA carbonatite complex for which $\mathrm{Mg} / \mathrm{Ca}$ and $\mathrm{Sr} / \mathrm{Ca}$ ratios have been reported by Gaetani and Cohen (2006). The resulting powder was collected in a Teflon beaker and dissolved in $2 \%$ $\mathrm{HNO}_{3}$. A polished piece from the same OKA calcite crystal was subsequently used in this study as reference material for SIMS after $\mathrm{Mn} / \mathrm{Ca}$ and $\mathrm{Fe} / \mathrm{Ca}$ ratios were determined by solution ICP-MS on the micromilled powder.

\subsubsection{Preparation of cross-sections for SIMS and microprobe analyses}

The cross-section of the $U$. peregrina specimen shown in Fig. 1 was prepared at the Alfred-Wegener-Institute Bremerhaven. The specimen was embedded in Araldite ${ }^{\mathrm{TM}}$ epoxy resin under vacuum inside a stainless steel chamber. Afterwards the chamber was set under pressure to eliminate any voids inside the resin after which the resin was hardened at $60^{\circ} \mathrm{C}$. The resin was ground down with alumo-silica grinding paper until the centre of the specimen was exposed. Subsequently the surface was polished using a silk cloth and $3 \mu \mathrm{m}$ diamond suspension followed by a final polishing step using $0.3 \mu \mathrm{m} \mathrm{Al}_{2} \mathrm{O}_{3}$ suspension. After each polishing step the surface was cleaned in a supersonic bath for a few seconds. 


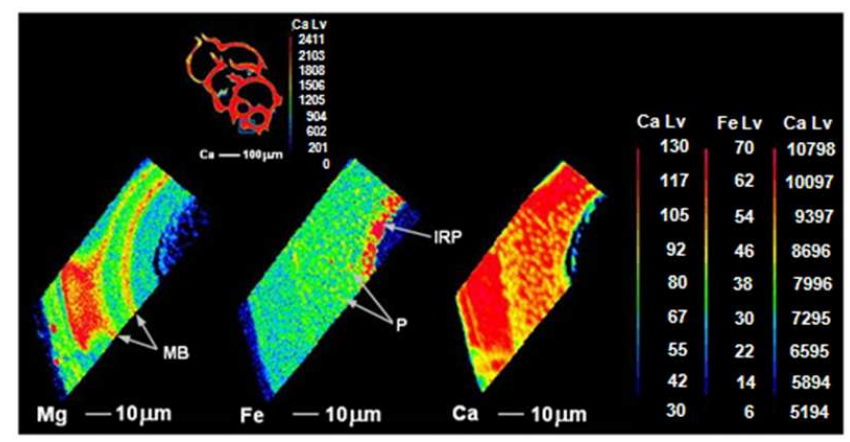

Fig. 1. EMP elemental mappings for an Uvigerina peregrina specimen from 519 m water depth (M77-1-421/MUC-13) on an exposed section of the foraminiferal test. Distribution of $\mathrm{Ca}, \mathrm{Mg}$ and $\mathrm{Fe}$ in the foraminiferal test. All intensity values are expressed in counts per second (cps) as shown in the color bars. MB: Mg bands IRP: Fe rich phase at inner test surface and pores $(\mathrm{P})$.

All other cross-sections were prepared at GEOMAR in Kiel. The U. peregrina specimens shown in Figs. 2 and 3 were embedded in epoxy resin under laboratory atmosphere. Afterwards they were ground by hand using alumu-silica grinding paper until the chambers were opened. Because the chambers were not filled with resin small drops of resin were used to fill the inner part of the chambers. The surface was then polished by hand with $5 \mu \mathrm{m}$ diamond paste followed by $1 \mu \mathrm{m}$ alumo-silica paste using a rotating polishing plate. After each polishing step the surface of the sample mount was cleaned in an ultrasonic bath for several seconds. All other specimens including all specimens of $B$. spissa were embedded under vacuum into Araldite ${ }^{\mathrm{TM}}$ epoxy resin using the CitoVac $^{\mathrm{TM}}$ vacuum embedding system by Struehrs ${ }^{\mathrm{TM}}$. The resin was ground down with alumo-silica grinding paper with the Tegra-Pol-21 system by Struehrs ${ }^{\mathrm{TM}}$ until the centre of the specimen was fully exposed. Afterwards the surface was polished with different grain sizes of alumo-silica and diamond paste until $1 \mu \mathrm{m}$ grain size. After each polishing step the surface was cleaned in an ultrasonic bath for several seconds.

\subsubsection{Elemental mapping with EMP}

A JEOL JXA 8200 electron microprobe was used to generate element distribution maps for $\mathrm{Ca}, \mathrm{Mn}, \mathrm{Fe}, \mathrm{Mg}, \mathrm{Ba}, \mathrm{Al}$, $\mathrm{Si}, \mathrm{S}$ and $\mathrm{P}$ within cross-sections of benthic foriminiferal test walls. Each cross-section was carbon coated before the measurements. The microprobe was operated in a wavelength dispersive mode by using different $\mathrm{K} \alpha \mathrm{X}$-ray lines for each element. Up to five spectrometers could be used to measure up to five elements simultaneously. The different spectrometer crystals which were used for the different elements are listed in the Appendix Table A1. An acceleration voltage of $15 \mathrm{kV}$ and a beam current of $20 \mathrm{nA}$ was used. The selected areas were mapped by using a step size of $0.5 \mu \mathrm{m}$ and a dwell time of $500 \mathrm{~ms}$. Results are illustrated as maps of relative measured intensities for the different elements. The JEOL JXA 8200 was also used to generate the secondary electron images of the foraminiferal cross-sections.

\subsubsection{SIMS analyses}

The $\mathrm{Mn} / \mathrm{Ca}$ and $\mathrm{Fe} / \mathrm{Ca}$ ratio analyses in test cross-sections of B. spissa were performed using a Cameca ims of magnetic sector ion microprobe at the Helmholtz Centre Potsdam. Each cross-section was ultrasonically cleaned twice in high purity ethanol prior to coating with a $35 \mathrm{~nm}$ thick, high purity gold coat.

Analyses used a $200 \mathrm{pA}$, nominally $12.5 \mathrm{kV}$, mass filtered ${ }^{16} \mathrm{O}^{-}$ion-beam which was focused to a diameter of ca. $4 \mu \mathrm{m}$ on the sample surface (see Fig. A1). Prior to each analysis the analytical location was presputtered for $300 \mathrm{~s}$ with the beam rastered over $10 \times 10 \mu \mathrm{m}$ raster followed by a second 3 min preburn with a static beam. During the first presputtering the ${ }^{40} \mathrm{Ca}^{+}$distribution was monitored using the dynamic ion imaging system of the instrument in order to improve the beam targeting on the thin walls of the test being investigated.

The mass spectrometer of the SIMS was operated at a mass resolution $M / \Delta M \approx 6000$, which is required in order to separate the ${ }^{55} \mathrm{Mn}$ peak from the isobaric ${ }^{54} \mathrm{Fe}^{1} \mathrm{H}$ molecule. A $150 \mu \mathrm{m}$ contrast aperture was used in conjunction with a $750 \mu \mathrm{m}$ field aperture (equivalent to a $60 \mu \mathrm{m}$ diameter field of view); no energy offset was employed and a $50 \mathrm{~V}$ wide energy window was used. A single analyses consisted of 30 scans of the sequence $39.95 \mathrm{Da}(0.1 \mathrm{~s}$ per cycle, used during the spot preburn), ${ }^{40} \mathrm{Ca}(2 \mathrm{~s}),{ }^{55} \mathrm{Mn}(10 \mathrm{~s}),{ }^{56} \mathrm{Fe}(4 \mathrm{~s})$ and ${ }^{63} \mathrm{Cu}(4 \mathrm{~s})$, resulting in a total data acquisition time of roughly $10 \mathrm{~min}$.

The OKA calcite was used as a reference material to convert the observed $\mathrm{Mn} / \mathrm{Ca}$ and $\mathrm{Fe} / \mathrm{Ca}$ count rate ratios into $\mu \mathrm{mol} \mathrm{mol}{ }^{-1}$ concentration values. It was analysed a total of $n=14$ times during our July 2010 analytical session, yielding a $1 \mathrm{sd}$ repeatability of $1.5 \%$ for the observed $\mathrm{Mn} / \mathrm{Ca}$, $14.8 \%$ for $\mathrm{Fe} / \mathrm{Ca}$ and $23.2 \%$ for $\mathrm{Cu} / \mathrm{Ca}$ ratios.

The test walls of $B$. spissa are generally quite thin (about $10-20 \mu \mathrm{m}$ thickness). The test is perforated; however the pores with a diameter of about $6 \mu \mathrm{m}$ are relatively big and easy to see on secondary electron images of the crosssections. Each analysis targeted a region of a test wall that had few or no pores so as to minimize any potentially contamination accumulated inside the pores. Subsequent to our SIMS session secondary electron images were made of the cross-sections in order to assess whether that SIMS ion beam was well focused and centered on the middle of the test wall. Measurements which were obviously done partly on epoxy or at the edge of the test wall or which showed low Ca count rates were discarded. All $\mathrm{Cu}$ measurements showed unexpectedly high ${ }^{63} \mathrm{Cu}$, for which we do not have an explanation. The $\mathrm{Cu}$ measurements have not been used in the data evaluation. 


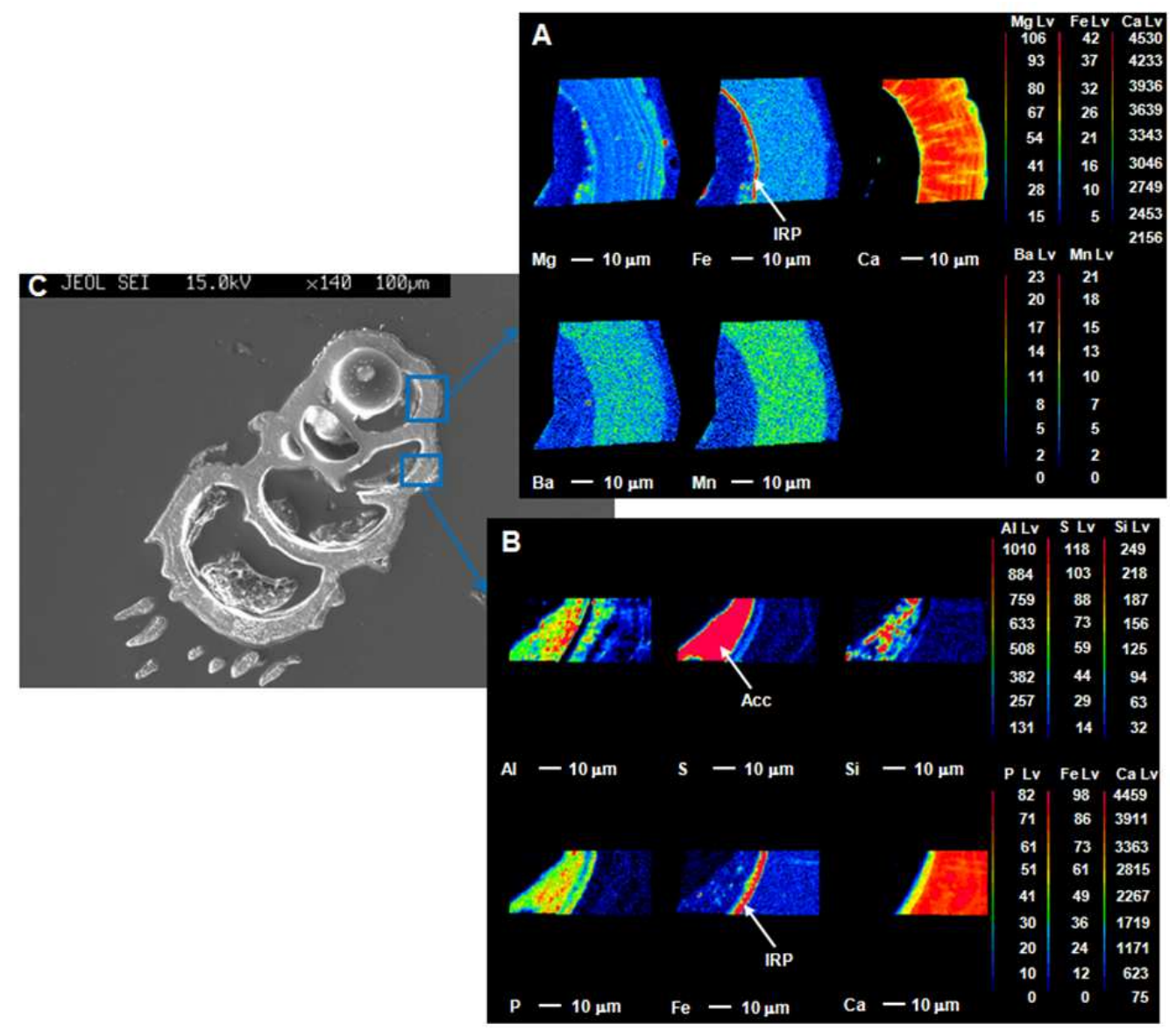

Fig. 2. EMP elemental mappings (A, B) and secondary electron image (C) for an Uvigerina peregrina specimen from $579 \mathrm{~m}$ water depth (M77-1-487/MUC-39) on an exposed section of the foraminiferal test. Distribution of Ca, Mg, Fe, Ba, Mn, Al, S, Si and P in the foraminiferal test. All intensity values are expressed in counts per second (cps) as shown in the color bars. IRP: Fe rich phase at inner test surface, Acc: accumulations inside the test chambers.

\subsection{Quadrupole ICP-MS analyses}

The analyses were performed on an Agilent $7500 \mathrm{cx}$ quadrupole ICP-MS. Operation conditions are listed in the Appendix Table A2. Instrument sensitivity was optimised by using of a $1 \mathrm{ppb}$ Li-Y-Tl-Ce-Mg-Co standard solution before the measurements. For sample introduction a microautosampler (Cetac ASX 100) coupled to a PFA selfaspiration nebulizer fitted to a glass spray chamber was used. Due to the small available sample volume (typically $\leq 500 \mu$ l) the low sample uptake rate of the self aspiration system was an important feature during the analyses. The integration times were $0.1 \mathrm{~s}$ for ${ }^{48} \mathrm{Ca}, 1 \mathrm{~s}$ for ${ }^{55} \mathrm{Mn}$ and $2 \mathrm{~s}$ for ${ }^{56} \mathrm{Fe}$ with 3 repetition runs. An octopole collision cell filled with $\mathrm{H}_{2}$ as reaction gas was used during the ${ }^{56} \mathrm{Fe}$ analyses to minimize interferences with ${ }^{40} \mathrm{Ar}^{16} \mathrm{O}$.

Dillutions were prepared from certified ICP-MS grade stock solutions $(10000 \mathrm{ppm}$ for $\mathrm{Ca}, 1000 \mathrm{ppm}$ for $\mathrm{Fe}$ and $\mathrm{Mn})$ by dilution with $2 \% \mathrm{HNO}_{3}$. The working standards were made by mixing the dilutions with $2 \% \mathrm{HNO}_{3}$ to give $\mathrm{Ca}$ concentrations of $10 \mathrm{ppm}$ and $\mathrm{Fe} / \mathrm{Ca}$ and $\mathrm{Mn} / \mathrm{Ca}$ ratios in the magnitude of foraminiferal calcite. The concentrations for the different standard rows are listed in Appendix Table A3. A second standard row with higher Mn concentrations was prepared for the analyses of the $\mathrm{Mn} / \mathrm{Ca}$ ratio in the OKA as well as a standard row for determination of Ca concentrations. About $50 \mu \mathrm{l}$ of the samples were diluted to $250 \mu \mathrm{l}$ first for the analyses of the $\mathrm{Ca}$ content. The remainder was diluted to $10 \mathrm{ppm} \mathrm{Ca}$ to overcome matrix effects during the element ratio determinations.

The measured $\mathrm{Mn} / \mathrm{Ca}$ and $\mathrm{Fe} / \mathrm{Ca}$ ratios for the Ecrm752, a limestone prepared under laboratory conditions (Greaves et al., 2008) and the OKA calcite grain are listed in Table 2. The Ecrm752 solution was used as internal reference standard for the ICP-MS analyses (mean $\mathrm{Mn} / \mathrm{Ca}=$ $139.3 \mu \mathrm{mol} \mathrm{mol}^{-1}$; mean $\left.\mathrm{Fe} / \mathrm{Ca}=155.3 \mu \mathrm{mol} \mathrm{mol}^{-1}\right)$. Element ratios for the Ecrm752 showed a high reproducibility with standard deviations of $4.0 \mu \mathrm{mol} \mathrm{mol}^{-1}(\mathrm{Mn} / \mathrm{Ca})$ and 


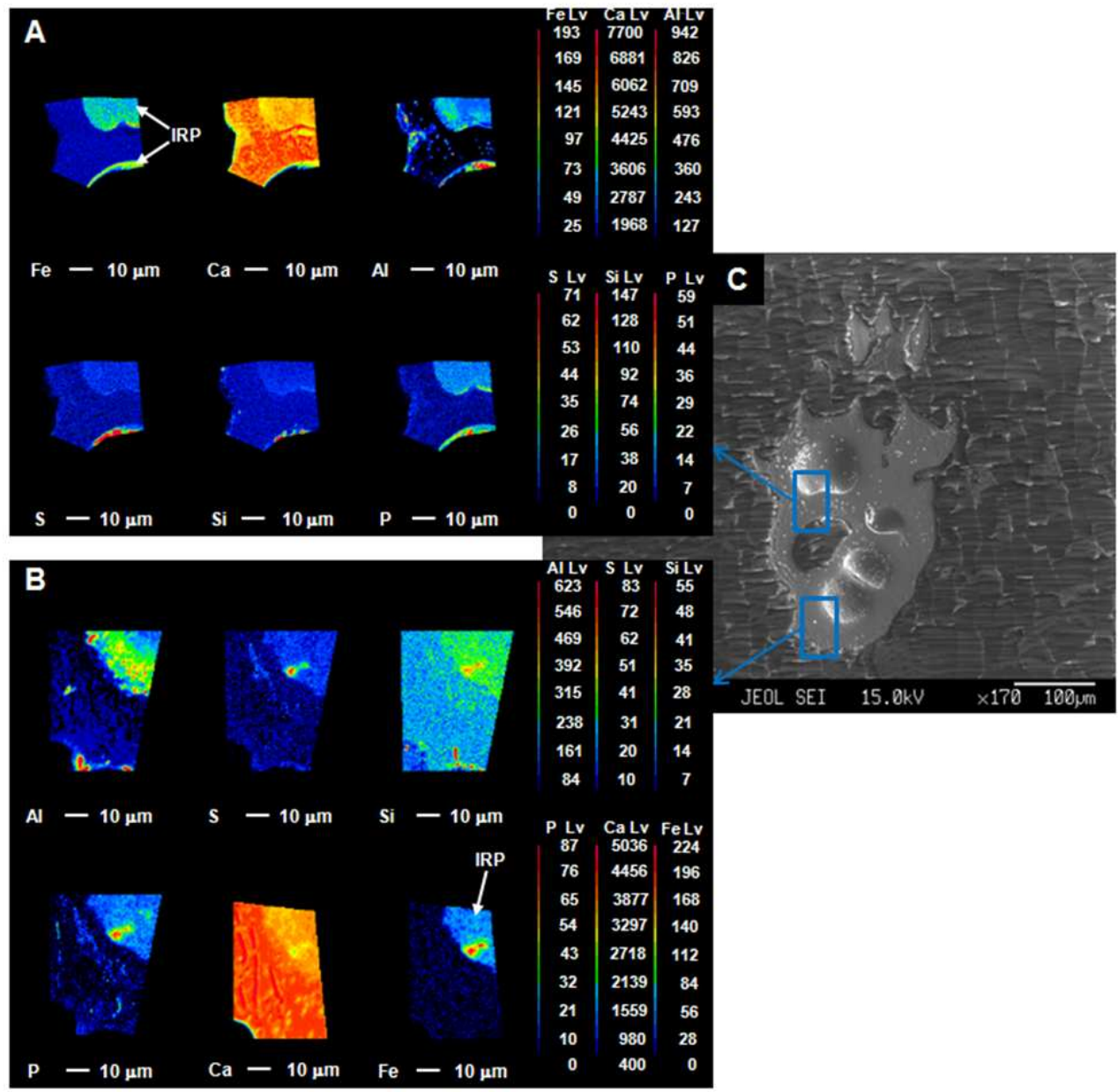

Fig. 3. EMP elemental mappings (A, B) and secondary electron image (C) for an Uvigerina peregrina specimen from $579 \mathrm{~m}$ water depth (M77-1-487/MUC-39) on an exposed section of the foraminiferal test. Distribution of Ca, Mg, Fe, Ba, Mn, Al, S, Si and P in the foraminiferal test. All intensity values are expressed in counts per second (cps) as shown in the color bars. IRP: Fe rich phase at inner test surface.

$5.2 \mu \mathrm{mol} \mathrm{mol}^{-1}(\mathrm{Fe} / \mathrm{Ca})$ between the different measurements. $\mathrm{The} \mathrm{Mn} / \mathrm{Ca}$ and $\mathrm{Fe} / \mathrm{Ca}$ ratios for the Ecrm752 have also been determined in an inter-laboratory calibration study (Greaves et al., 2008). The data presented in our study are in accordance to the values reported for the uncentrifuged Ecrm752 where the $\mathrm{Mn} / \mathrm{Ca}$ ratio ranged from $121-147 \mu \mathrm{mol} \mathrm{mol}^{-1}$ and the $\mathrm{Fe} / \mathrm{Ca}$ ratio ranged from $97-220 \mu \mathrm{mol} \mathrm{mol}^{-1}$ between the different laboratories. The mean element ratios for the Oka calcite grain which was used as cross calibration standard for the SIMS analyses was also determined with ICP-MS (mean $\mathrm{Mn} / \mathrm{Ca}=4930.3 \mu \mathrm{mol} \mathrm{mol}^{-1}$; mean $\mathrm{Fe} / \mathrm{Ca}=$ $\left.541.3 \mu \mathrm{mol} \mathrm{mol}^{-1}\right)$.

\section{Results}

\subsection{EMP maps of $U$. peregrina and $B$. spissa tests}

Several trace element distribution maps on uncleaned tests of $U$. peregrina and B. spissa are shown in Figs. 1-4. While $U$. peregrina shows strong Mg-bands (Figs. 1 and 2), typical for the primary calcite in tests of bilaminated calcitic foraminifera, B. spissa completely lacks these bands. The inner parts of the walls in both species are highly enriched in iron. A slight iron enrichment is also present in the pores of $U$. peregrina (Fig. 1). The iron rich inner phases inside $U$. peregrina are also enriched in $\mathrm{Al}, \mathrm{Si}, \mathrm{P}$ and $\mathrm{S}$ (Figs. 2 and 3 ) which hints towards a presence of alumo-silicates (clays) and organic matter. Additionally there are accumulations present inside the test chambers of $U$. peregrina. These accumulations differ in their chemical composition from the iron rich phase at the inner parts of the wall (less $\mathrm{Fe}$ and $\mathrm{Ca}$, more $\mathrm{S}$ and P) (Fig. 2). The chemical composition of two 
Table 2. Element/Ca ratios for different samples determined by ICP-MS.

\begin{tabular}{lllll}
\hline Material & $\begin{array}{l}\mathrm{Mn} / \mathrm{Ca} \\
\left.(\mu \mathrm{mol} \mathrm{mol})^{-1}\right)\end{array}$ & $\begin{array}{l}1 \sigma \\
\left(\mu \mathrm{mol} \mathrm{mol}^{-1}\right)\end{array}$ & $\begin{array}{l}\mathrm{Fe} / \mathrm{Ca} \\
\left(\mu \mathrm{mol} \mathrm{mol}^{-1}\right)\end{array}$ & $\begin{array}{l}1 \sigma \\
\left.(\mu \mathrm{mol} \mathrm{mol})^{-1}\right)\end{array}$ \\
\hline Ecrm752 & 148.30 & 10.7 & 150.1 & 9.8 \\
Ecrm752 & 138.20 & 2.8 & 150.1 & 8.0 \\
Ecrm752 & 137.70 & 2.1 & 150.3 & 7.9 \\
Ecrm752 & 137.80 & 1.5 & 157.3 & 3.5 \\
Ecrm752 & 138.30 & 1.4 & 157.1 & 4.5 \\
Ecrm752 & 138.30 & 3.7 & 159.0 & 5.1 \\
Ecrm752 & 136.50 & 1.7 & 163.1 & 1.4 \\
Oka & 4942.00 & 57.8 & 547.7 & 10.3 \\
Oka & 4875.60 & 181.4 & 523.1 & 12.8 \\
Oka & 4973.40 & 54.7 & 553.2 & 5.5 \\
B. spissa M77-1-455/MUC-21 & 3.80 & 0.06 & 87.0 & 3.2 \\
B. spissa M77-1-487/MUC-38 & & & 142.0 & 3.1 \\
B. spissa M77-1-487/MUC-38 & & & 157.5 & 2.1 \\
B. spissa M77-1-565/MUC-60 & & & 160.6 & 3.2 \\
B. spissa M77-1-565/MUC-60 & & & 138.1 & 2.9 \\
\hline
\end{tabular}

cuts directly through layers of this iron rich phase is shown in Fig. 3. The element maps show the transition from the calcitic test walls into this iron rich phase. Trace element distribution maps in a test section of an $U$. peregrina specimen and two specimens of $B$. spissa treated with an oxidative cleaning are shown in Figs. 5-7. The Fe rich phases are absent in these cleaned specimens except in a pore of the specimen from $465 \mathrm{~m}$ water depth (Fig. 7). All Ca distributions in the test walls of $B$. spissa show strongly heterogenous patterns. These patterns can be recognized on secondary-electron (SE) and backscattered-electron (BSE) images, too (Fig. 8). These images have been made after the mappings. The BSE images show that these structures look like some kind of porous bands in the test walls where the Ca maps show higher count rates.

\subsection{Elemental ratios from SIMS and ICP-MS}

The measured $\mathrm{Mn} / \mathrm{Ca}$ and $\mathrm{Fe} / \mathrm{Ca}$ ratios in tests of $\mathrm{B}$. spissa are listed in Table 2 (ICP-MS), Table 3 (SIMS) and Table 4 (mean SIMS) and shown in Fig. 9. The mean ratios from the SIMS spot analyses for single specimens are plotted as well as the ratios from ICP-MS analyses on bulk solutions of several specimens. Bulk ratios agree to the microanalyses in maximal differences of 3-29\% compared to the overall data range between the different sampling sites, although the $\mathrm{Mn} / \mathrm{Ca}$ ratio from the bulk analysis is slightly elevated compared to the microanalysis result $\left(3.8 \mu \mathrm{mol} \mathrm{mol}^{-1}\right.$ compared to $2.12 \mu \mathrm{mol} \mathrm{mol}^{-1}$ ). The $\mathrm{Mn} / \mathrm{Ca}$ ratios fall in a relatively low range of $2.12-9.93 \mu \mathrm{mol} \mathrm{mol}^{-1}$, far below the generally accepted level of $\mathrm{Mn} / \mathrm{Ca}$ to prove the absence of diagenetic coatings from $50 \mu \mathrm{mol} \mathrm{mol}^{-1}$ to $>150 \mu \mathrm{mol} \mathrm{mol}^{-1}$ (Boyle, 1983; Boyle and Keigwin, 1985, 1986; Delaney, 1990; Ohk-

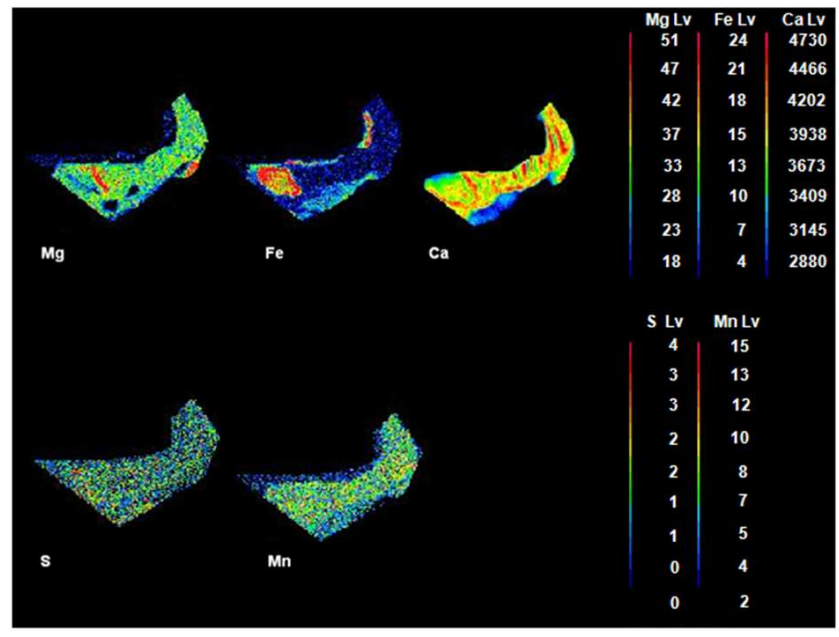

Fig. 4. EMP elemental mapping of a section from an uncleaned $B o-$ livina spissa specimen from $640 \mathrm{~m}$ water depth (M77-1-565/MUC$60)$ on an exposed section of the foraminiferal test. Distribution of $\mathrm{Mg}, \mathrm{Fe}, \mathrm{Mn}, \mathrm{S}$ and $\mathrm{Ca}$ in the foraminiferal test. All intensity values are expressed in counts per second (cps) as shown in the color bars. Note that the Fe distribution shows a contaminant phase a the inner part of the test walls similar like the uncleaned specimens of $U$. peregrina.

ouchi et al., 1994). The corresponding Fe/Ca ratios range from $87.0-551.8 \mu \mathrm{mol} \mathrm{mol}^{-1}$. Both element ratios show an increasing trend towards deeper water depths and higher bottom water oxygenation. The standard deviations between the different SIMS spots on single specimens are generally higher among the specimens from the deeper and better oxygenated locations. They range from $0.37-5.91 \mu \mathrm{mol} \mathrm{mol}^{-1}$ 
Table 3. Element/Ca ratios of foraminiferal calcite determined by SIMS.

\begin{tabular}{lllll}
\hline Material & $\begin{array}{l}\mathrm{Mn} / \mathrm{Ca} \\
(\mu \mathrm{mol} \mathrm{mol}-1)\end{array}$ & $\begin{array}{l}1 \sigma \\
(\mu \mathrm{mol} \mathrm{mol}-1)\end{array}$ & $\begin{array}{l}\mathrm{Fe} / \mathrm{Ca} \\
(\mu \mathrm{mol} \mathrm{mol}-1)\end{array}$ & $\begin{array}{l}1 \sigma \\
\left(\mu \mathrm{mol} \mathrm{mol}{ }^{-1}\right)\end{array}$ \\
\hline B. spissa M77-1-455/MUC-21 & 1.68 & 0.53 & 108.2 & 9.7 \\
B. spissa M77-1-455/MUC-21 & 2.32 & 0.60 & 66.9 & 8.7 \\
B. spissa M77-1-455/MUC-21 & 2.02 & 0.61 & 117.2 & 10.1 \\
B. spissa M77-1-455/MUC-21 & 2.46 & 0.64 & 111.6 & 10.2 \\
B. spissa M77-1-487/MUC-38a & 5.71 & 1.01 & 82.4 & 8.7 \\
B. spissa M77-1-487/MUC-38a & 5.15 & 0.94 & 185.0 & 12.6 \\
B. spissa M77-1-487/MUC-38b & 3.48 & 0.76 & 227.7 & 14.3 \\
B. spissa M77-1-487/MUC-38b & 6.48 & 1.02 & 218.4 & 14.5 \\
B. spissa M77-1-487/MUC-38b & 7.46 & 1.18 & 119.2 & 10.7 \\
B. spissa M77-1-565/MUC-60a & 2.82 & 0.69 & 48.7 & 6.1 \\
B. spissa M77-1-565/MUC-60a & 4.44 & 0.81 & 84.1 & 6.2 \\
B. spissa M77-1-565/MUC-60a & 6.20 & 0.92 & 164.1 & 12.3 \\
B. spissa M77-1-565/MUC-60a & 5.61 & 0.88 & 78.6 & 8.3 \\
B. spissa M77-1-565/MUC-60b & 2.31 & 0.58 & 180.4 & 12.1 \\
B. spissa M77-1-565/MUC-60b & 3.51 & 0.76 & 269.8 & 16.1 \\
B. spissa M77-1-565/MUC-60b & 2.76 & 0.62 & 423.2 & 18.5 \\
B. spissa M77-1-565/MUC-60b & 3.01 & 0.63 & 218.3 & 12.7 \\
B. spissa M77-1-604/MUC-74 & 5.29 & 0.89 & 216.8 & 13.2 \\
B. spissa M77-1-604/MUC-74 & 16.59 & 2.85 & 984.4 & 78.8 \\
B. spissa M77-1-445/MUC-15 & 9.97 & 1.23 & 420.5 & 21.7 \\
B. spissa M77-1-445/MUC-15 & 5.57 & 1.04 & 853.5 & 30.0 \\
B. spissa M77-1-445/MUC-15 & 3.14 & 0.72 & 72.1 & 8.3 \\
B. spissa M77-1-445/MUC-15 & 8.02 & 1.17 & 805.8 & 91.9 \\
\hline
\end{tabular}

Table 4. Mean element/Ca ratios in tests of single B. spissa specimens determined with SIMS. $1 \sigma$ is representing the intra test variability inside the single specimens.

\begin{tabular}{lllll}
\hline Material & $\begin{array}{l}\mathrm{Mn} / \mathrm{Ca} \\
(\mu \mathrm{mol} \mathrm{mol}-1)\end{array}$ & $\begin{array}{l}1 \sigma \\
\left(\mu \mathrm{mol} \mathrm{mol}^{-1}\right)\end{array}$ & $\begin{array}{l}\mathrm{Fe} / \mathrm{Ca} \\
\left(\mu \mathrm{mol} \mathrm{mol}^{-1}\right)\end{array}$ & $\begin{array}{l}1 \sigma \\
\left(\mu \mathrm{mol} \mathrm{mol}^{-1}\right)\end{array}$ \\
\hline B. spissa M77-1-455/MUC-21 & 2.12 & 0.35 & 101.0 & 23.1 \\
B. spissa M77-1-487/MUC-38a & 5.15 & & 185.0 & \\
B. spissa M77-1-487/MUC-38b & 5.81 & 2.07 & 188.4 & 60.1 \\
B. spissa M77-1-565/MUC-60a & 4.77 & 1.48 & 93.9 & 49.3 \\
B. spissa M77-1-565/MUC-60b & 2.90 & 0.50 & 272.9 & 106.7 \\
B. spissa M77-1-604/MUC-74 & 9.93 & 5.91 & 551.8 & 393.0 \\
B. spissa M77-1-445/MUC-15 & 6.67 & 2.96 & 538.0 & 366.1 \\
\hline
\end{tabular}

for the $\mathrm{Mn} / \mathrm{Ca}$ and from $23.1-393.0 \mu \mathrm{mol} \mathrm{mol}^{-1}$ for the $\mathrm{Fe} / \mathrm{Ca}$ ratio. The $\mathrm{Mn} / \mathrm{Ca}$ and $\mathrm{Fe} / \mathrm{Ca}$ ratios for an uncleaned specimen of B. spissa are shown in Fig. 9 indicated by a green diamond. Compared to a specimen from the same sampling site treated with oxidative cleaning, it shows an elevated $\mathrm{Fe} / \mathrm{Ca}$ ratio and a slightly reduced $\mathrm{Mn} / \mathrm{Ca}$ ratio.

\subsection{Comparison to pore-water data}

The positive correlation between $\mathrm{Mn} / \mathrm{Ca}$ in tests of $\mathrm{B}$. spissa and in ambient pore waters (Scholz et al., 2011) are shown in Fig. 10a. The Fe/Ca ratios in B. spissa on the other show a negative correlation to the ratios in ambient pore waters (Fig. 10b). The core from the shallowest and most oxygendepleted sampling site shows a sharp Fe peak with high $\mathrm{Fe}$ concentrations in the top $2 \mathrm{~cm}$ of the pore waters (Scholz et al., 2011). In contrast to this high Fe concentrations in the ambient pore waters the $\mathrm{Fe} / \mathrm{Ca}$ ratios in tests of $\mathrm{B}$. spissa from this location are the lowest among all samples. 


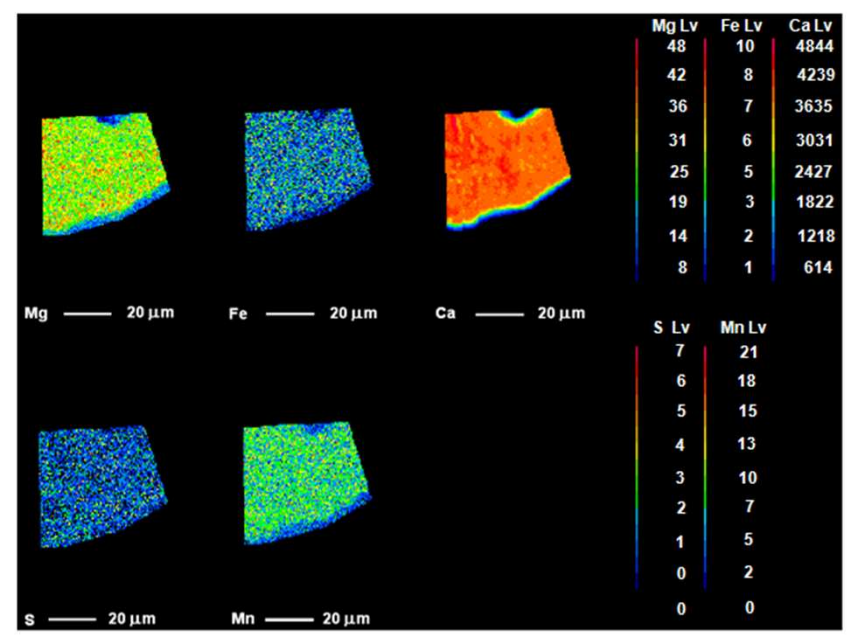

Fig. 5. EMP elemental mapping of a section from an Uvigerina peregrina specimen from $640 \mathrm{~m}$ water depth (M77-1-565/MUC-60) on an exposed section of the foraminiferal test treated with an oxidative cleaning procedure. Distribution of $\mathrm{Mg}, \mathrm{Fe}, \mathrm{Mn}, \mathrm{S}$ and $\mathrm{Ca}$ in the foraminiferal test. All intensity values are expressed in counts per second (cps) as shown in the color bars. Note that no contaminant phases are visible in the Fe distribution.

\section{Discussion}

\subsection{Chemical test microstructure of $U$. peregrina and B. spissa}

The trace element mappings of $U$. peregrina cross-sections show an iron rich phase which is also strongly enriched in other elements (Figs. 1-3). This phase seems to be similar to "coatings" which have been found in the inner chamber walls of Globigerinoides ruber (Gehlen et al., 2004). Since this phase is removed after an oxidative cleaning without a reductive cleaning step, it should not represent an (oxyhydr)oxide coating. Also the low Mn content shows that it does not consist of manganese carbonate. It has more chemical similarity with cements in tests of several agglutinated foraminifera and the test walls of several allogromiids (Bertram and Cowen, 1998; Gooday et al., 2008).

The accumulations inside the test walls of the $U$. peregrina specimen shown in Fig. 2 most probable consist of organic detritus as remainings of deposit feeding, although mud accumulations from the sediments after their death cannot be excluded. Deposit feeding and the accumulation of organic detritus in living specimens of $U$. peregrina have been documented by Goldstein and Corliss (1994). The complete difference in the chemical composition of these accumulations compared to the Fe rich phase at the inner wall surface makes the suggestion that this lining consists of remaining clay and other sediment particles from food vacuoles agglutinated to the inner test wall very unreasonable. The fact that $B$. spissa does not feed on organic detritus but on phytodetritus (No-

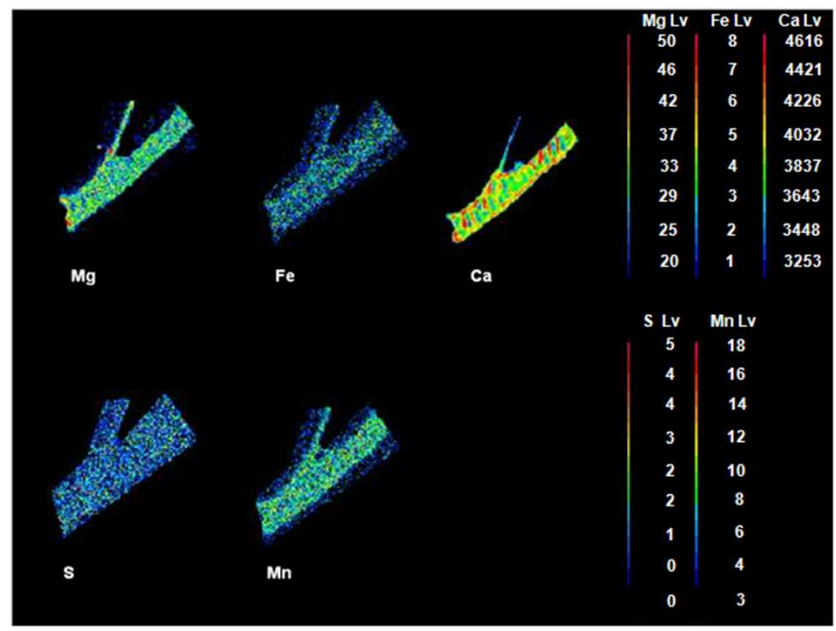

Fig. 6. EMP elemental mapping of a section from a Bolivina spissa from $640 \mathrm{~m}$ water depth (M77-1-565/MUC-60) on an exposed section of the foraminiferal test specimen treated with an oxidative cleaning procedure. Distribution of $\mathrm{Mg}, \mathrm{Fe}, \mathrm{Mn}, \mathrm{S}$ and $\mathrm{Ca}$ in the foraminiferal test. All intensity values are expressed in counts per second (cps) as shown in the color bars. Note that no contaminant phases are visible in the Fe distribution.

maki et al., 2006) might explain the absence of these accumulations in tests of $B$. spissa.

The element mappings in both $U$. peregrina and $B$. spissa show no hints of ferro-manganese-oxide coatings which is most likely related to the highly reducing conditions in the pore waters at the OMZ off Peru. At least for shallow samples a reductive cleaning procedure seems to be unnecessary. The comparison between the uncleaned specimens with the specimens treated with an oxidative cleaning show that the oxidative cleaning removes the contaminant $\mathrm{Fe}$ rich phase at the inner surface of the test walls. To minimize contaminations during the microanalysis of foraminiferal tests it is necessary to use an oxidative cleaning step during sample preparation. But even after intense oxidative cleaning there are still contaminations left inside the test pores (Fig. 7). Thus it should be avoided to measure parts of the tests where pores are present. This might be especially complicated during the analyses of foraminifera with a high pore-density with laser ablation due to the spot diameter $(50-80 \mu \mathrm{m})$ required for low concentration measurements on Q-ICP-MS. Bolivinidae like B. spissa have porosities around $20 \%$ (Glock et al. 2011) while planktic foraminifera could also reach porosities higher than $20 \%$ (Bé, 1968). These numbers just represent the overall porosities. On test areas of high pore concentrations the porosities can reach much higher values. The relative Fe count rates are 2-4 times higher at areas where the $\mathrm{Fe}$ rich phase is present while the $\mathrm{Ca}$ count rates are slightly decreased. Thus, measuring on test areas of high porosity could have significant influence on several element/Ca ratios. Nevertheless, the test walls seem to be contamination 


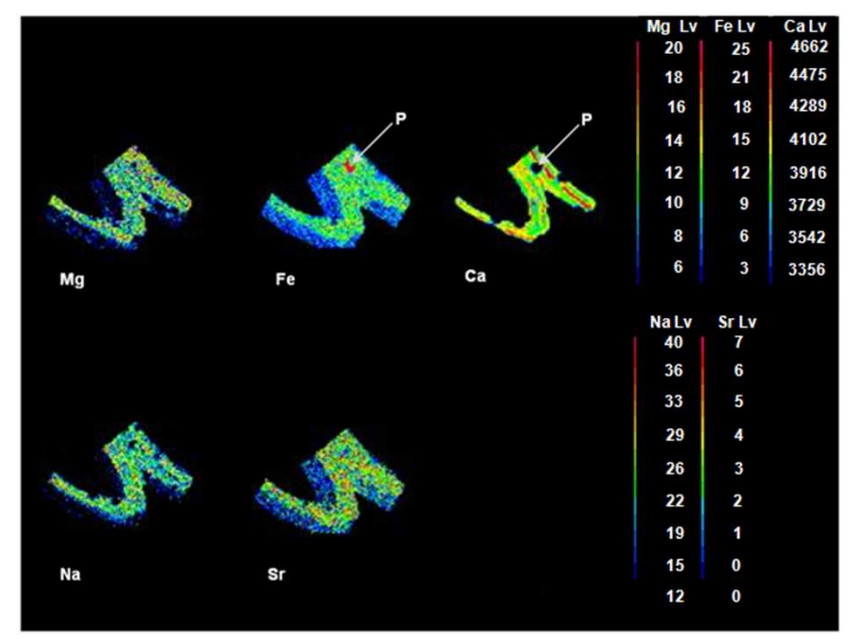

Fig. 7. EMP elemental mapping of a section from a Bolivina spissa from $465 \mathrm{~m}$ water depth (M77-1-455/MUC-21) on an exposed section of the foraminiferal test specimen treated with an oxidative cleaning procedure. Distribution of $\mathrm{Mg}, \mathrm{Fe}, \mathrm{Mn}, \mathrm{S}$ and $\mathrm{Ca}$ in the foraminiferal test. All intensity values are expressed in counts per second (cps) as shown in the color bars. Note that no contaminant phases are visible in the Fe distribution except inside a test pore (P).

free after the oxidative cleaning where no pores are present. The element/Ca ratios measured with SIMS in the tests of the cleaned B. spissa specimens should therefore represent the element/Ca ratios of the test calcite. This might be more complicated by presence of any diagenetic oxyhdroxide or Mn carbonate coatings. In this case EMP mappings should be used as pre-investigation to locate these coatings. Additionally the efficiancy of a reductive cleaning treatment could be analysed by EMP mapping by comparing cleaned and uncleaned specimens.

The strong Mg-bends present in $U$. peregrina are not visible in B. spissa. This might be explained by the fact that bolivinidae construct their tests in a monolamellar concept without a second phase of calcite between the different layers (Sliter, 1974).

Still enigmatic remain the heterogeneous patterns in $\mathrm{Ca}$ distribution. The $\mathrm{Ca}$ count rates are higher where these porous structures are visuable in the BSE images. This appears to be puzzling because in this case the $\mathrm{Ca}$ concentration would be higher at spots of low density. Thus it is probable that the higher $\mathrm{Ca}$ count rates in the holey structures are rather artifacts due to topography related analytical problems with. It seems likely that the high energetic X-ray beam pitted the surface of the sample by burning more volatile parts of the test wall.

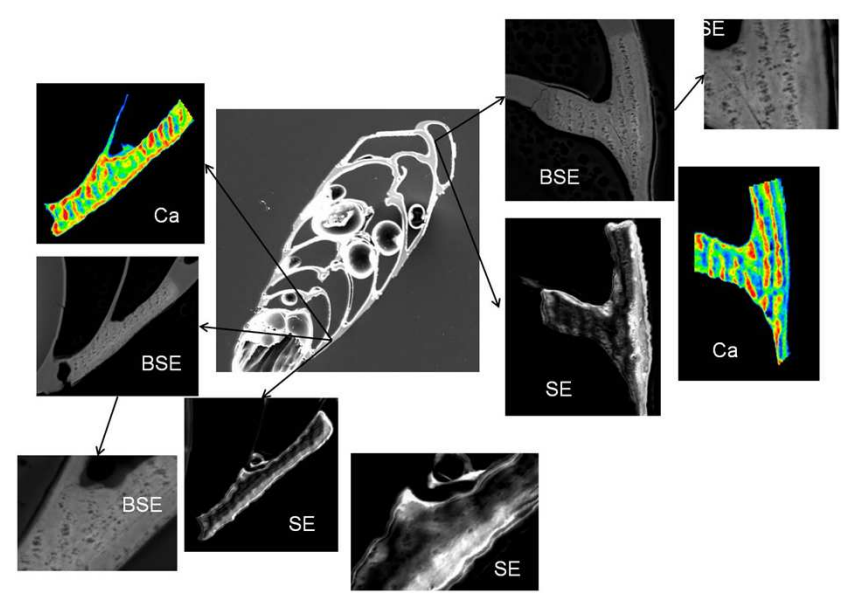

Fig. 8. Cross section of a Bolivina spissa specimen from 640 $\mathrm{m}$ water depth (M77-1-565/MUC-60) with a secondary electron overview image in the middle. Close ups of sections of Ca-EMP mappings (Ca) secondary electron images (SE) and backscattered electron images (BSE) are shown. Note that the Ca distribution is reflected by the holey structures seen on the BSE images.

\subsection{Redox sensitive elements in pore waters and B. spissa}

\subsection{1 $\mathrm{Mn} / \mathrm{Ca}$ ratios}

Reductive dissolution of reactive Mn (oxyhydr)oxides in the surface sediments drive the Mn flux across the benthic boundary (Froelich et al., 1987; Burdige et al., 1993; Pakhomova et al., 2007; Scholz et al., 2011). The Mn concentrations and the related $\mathrm{Mn} / \mathrm{Ca}$ ratios are relatively low in the pore waters from the OMZ off Peru since most of the Mn delivered to the $\mathrm{OMZ}$ is already reduced in the water column, and hence only minor amounts of particulate bound Mn settle down to the seafloor (Böning et al., 2004; Scholz et al., 2011).The $\mathrm{Mn} / \mathrm{Ca}$ ratios in tests of B. spissa are relatively low, too, and show a slightly increasing trend with higher bottom water oxygenation. At a first glance these results appear to be confusing because usually solid $\mathrm{MnO}_{2}$ is rapidly reduced to soluble $\mathrm{Mn}^{2+}$ in oxygen depleted pore waters. Thus, it is expected that Mn concentrations are elevated in the top pore water interval when bottom water oxygen is depleted. Even if the pore water conditions are highly reducing, only little Mn can be mobilised due to the absence of particulate $\mathrm{MnO}_{2}$. At deeper water depths below the OMZ the oxygen concentration starts to rise again slightly and soluble $\mathrm{Mn}^{2+}$ might be oxidized slowly to $\mathrm{MnO}_{2}$ and precipitate at the sediment surface. Thus at the deeper sampling locations the Mn concentrations in the top pore water intervals are slightly higher due to the recycling of $\mathrm{Mn}$ near the sediment water interface (Scholz et al., 2011). The $\mathrm{Mn} / \mathrm{Ca}$ ratios in B. spissa seem to reflect these conditions, too. Thus, these initial results might be used to interpret downcore profiles 

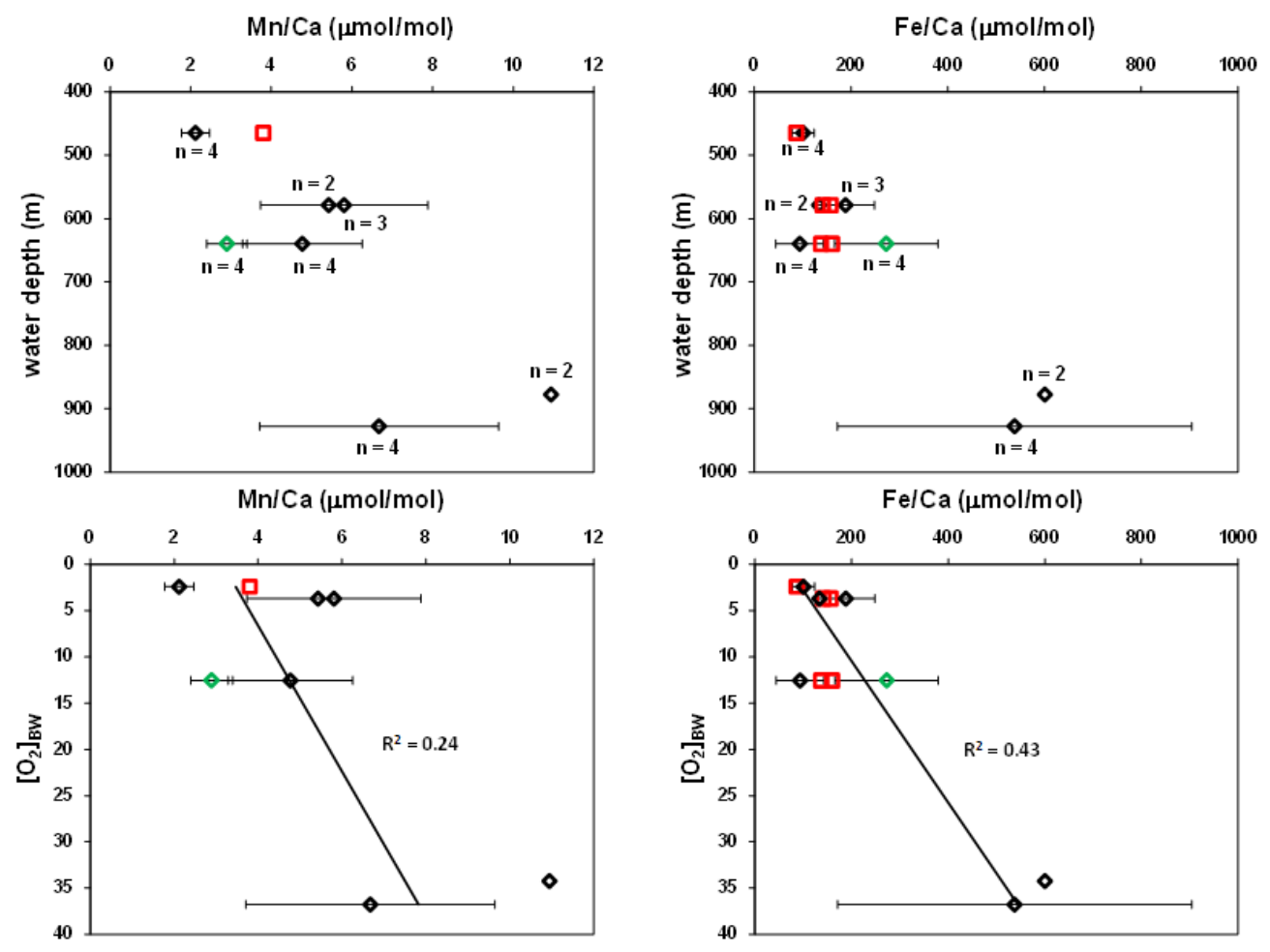

Fig. 9. $\mathrm{Mn} / \mathrm{Ca}$ and $\mathrm{Fe} / \mathrm{Ca}$ ratios in tests of Bolivina spissa plotted against water depth and $\left[\mathrm{O}_{2}\right]_{\mathrm{BW}}$. Red squares indicate data points measured on bulk samples of 40 specimens with ICP-MS while diamonds indicate mean values from single specimens measured with SIMS. The specimens indicated by the black diamonds all have been treated with an oxidative cleaning procedure while the single green diamond represents an uncleaned specimen. Error bars on the SIMS data show the standard deviation between the different spots measured on a single specimen. Diamonds without error bars indicate mean values of only two measurements. The linear fits and their $R^{2}$ value are calculated from all measured datapoints, not from the mean values plotted here.
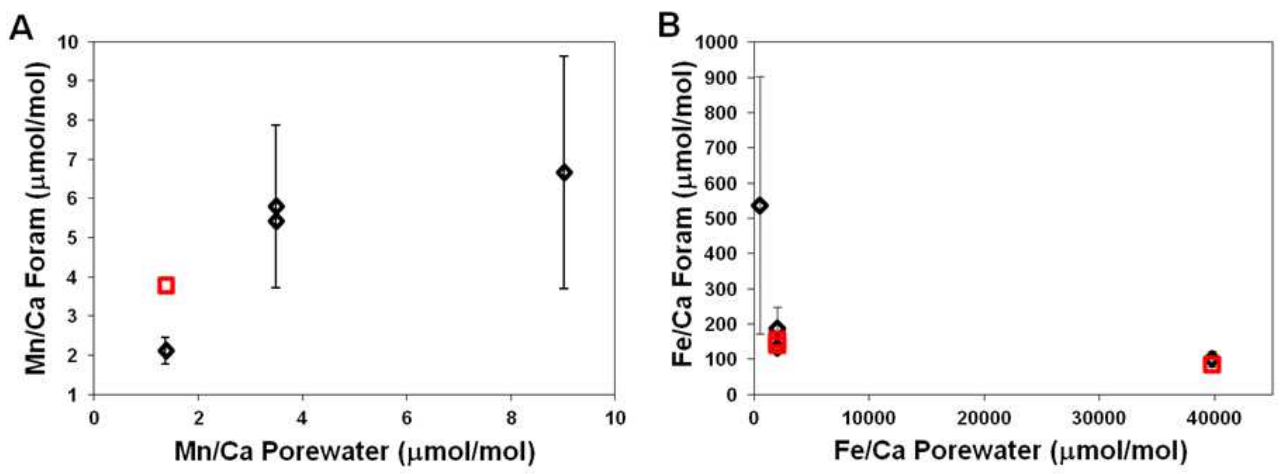

Fig. 10. Correlation between the $\mathrm{Mn} / \mathrm{Ca}(\mathbf{A})$ and $\mathrm{Fe} / \mathrm{Ca}(\mathbf{B})$ ratios in tests of Bolivina spissa to the $\mathrm{Mn} / \mathrm{Ca}$ and $\mathrm{Fe} / \mathrm{Ca}$ ratios in the top cm of the pore water from the same sampling location. Red squares indicate data points measured on bulk samples of 40 specimens with ICP-MS while black diamonds indicate mean values from single specimens measured with SIMS. Error bars on the SIMS data show the standard deviation between the different spots measured on a single specimen.

of $\mathrm{Mn} / \mathrm{Ca}$ ratios in benthic foraminifera from the Peruvian OMZ. Elevated $\mathrm{Mn} / \mathrm{Ca}$ ratios would indicate higher oxygen concentrations during this time due to a higher $\mathrm{MnO}_{2}$ flux to the seafloor.

\subsection{2 $\mathrm{Fe} / \mathrm{Ca}$ ratios and comparison to pore waters}

Initial results indicate a negative correlation between the $\mathrm{Fe} / \mathrm{Ca}$ ratios in B. spissa and the concentrations in the pore waters. At the deepest station $(928 \mathrm{~m})$ the $\mathrm{Fe} / \mathrm{Ca}$ ratio in 
B. spissa $\left(538.0 \mu \mathrm{mol} \mathrm{mol}^{-1}\right)$ is in the same order of magnitude as in the surrounding pore waters $\left(513.3 \mu \mathrm{mol} \mathrm{mol}^{-1}\right.$; Fe concentrations from Scholz et al., 2011). However, the lowest foraminiferal $\mathrm{Fe} / \mathrm{Ca}$ ratios $\left(87.0-101.0 \mu \mathrm{mol} \mathrm{mol}^{-1}\right)$ were found at $465 \mathrm{~m}$ water depth, a location with a strong sharp Fe peak in the pore water at the sediment surface and respectively, high $\mathrm{Fe} / \mathrm{Ca}$ ratios in the surrounding pore waters $\left(39754.1 \mu \mathrm{mol} \mathrm{mol}^{-1}\right.$; Fe concentrations from Scholz et al., 2011). No living specimens of B. spissa were found at this location during sampling time (Mallon et al., 2011) although a very high amount of dead tests was present. At the two other sampling locations where pore water profiles are available (579 and $928 \mathrm{~m}$ water depth) living specimens of $B$. spissa could be found during sampling time (Mallon et al., 2011). In the centre of the OMZ B. spissa is completely absent (Glock et al., 2011). This suggests that $B$. spissa needs at least trace amounts of oxygen to survive or enough nitrate for denitrification, since B. spissa is known to accumulate nitrate and seem to adapt their pore-density to nitrate availability (Glud et al., 2009; Glock et al. 2011). At the Peruvian OMZ B. spissa can be found in temperature ranges from 4.8-13.0 ${ }^{\circ} \mathrm{C}$ (Glock et al., 2011) and foraminifera in general are known for good adaptation to fluctuations in salinity by change of their surface to volume ratio through variation of volume and number of vacuoles inside their cell (Erez et al., 2011). Thus, the fluctuation of these two factors in at this location is not high enough to kill B. spissa. Another factor which might kill $B$. spissa in anoxic habitats is the presence of high sulphide concentrations. Furthermore, on the one hand B. spissa is known for its seasonality (Silva et al., 1996; Nomaki et al., 2006) which on the other hand would not explain the presence of living B. spissa at the deeper sampling locations (Mallon et al., 2011).

A likely scenario, which can explain all observations and facts outlined above is that the habitat only recently turned anoxic causing the death of high numbers of B. spissa. Periodic shifts of the OMZs upper boundary are well known (Guitiérrez et al., 2008; Scholz et al., 2011). Shelf oxygenation events occur consistent with the propagation of coastal trapped waves (CTW). These CTWs occur more frequently during El-Nino events but not all of the oxygenated episodes occur during El-Nino. Higher oxygen levels on the upper Peruvian shelf during El-Nino events have also been observed before (Levin et al., 2002). Although the current knowledge about El-Nino indicate that its oceanographic effects on the Southeast Pacific might not result directly in a significant increase of oxygen levels at deeper waters in the OMZ (Strub et al., 1998; Levin et al., 2002), a reduction in the input of fresh organic carbon occurs during El-Nino (Levin et al., 2002), which might indirectly influence the oxygen levels in the deeper bottom waters, too. Furthermore, the bottom water oxygen concentration during El-Nino at $562 \mathrm{~m}$ water depth near the lower OMZ boundary during El-Nino at $12^{\circ} \mathrm{S}$ $\left(11.61 \mu \mathrm{moll}^{-1}\right.$, Levin et al., 2002) was strongly elevated compared to a location from similar water depths $(579 \mathrm{~m})$ at $11^{\circ} \mathrm{S}$ during non-El-Nino conditions $\left(3.7 \mu \mathrm{mol} \mathrm{l}^{-1}\right.$, Glock et al., 2011). Thus, B. spissa might live at the location at $465 \mathrm{~m}$ water depth during such episodes of higher oxygen supply. Fast adaptation of faunal communities in the Peruvian OMZ to oxygen supply has been described before (Levin et al., 2002; Guitiérrez et al., 2008).

During episodes of shelf oxygenation $\mathrm{Fe}$, delivered through lateral transport from sediments in the center of the OMZ, is oxidized at the upper boundary of the OMZ (Scholz et al., 2011). This and the supply of detrital (oxyhydr)oxides from the continent leads to high pore water Fe concentrations at the upper boundary of the OMZ during anoxic episodes (Suits and Arthur, 2000; Scholz et al., 2011). The similar but less distinctive subsurface Fe peak in the pore waters at $465 \mathrm{~m}$ (Scholz et al., 2011) is possibly the result of fluctuations in the lower OMZ boundary due to fluctuations in the input of fresh organic carbon. These are less distinctive than the fluctuations in the upper boundary caused by CTWs. As a consequence, enhanced Fe release from the sediment surface most likely started after the bottom water turned anoxic again, postmortal of B. spissa, so that the Fe could not be incorporated into the test calcite anymore.

Thus, the high Fe fluxes near the OMZ boundaries are typically only short lived and either levelled out after longer anoxic periods or completely turned down during more oxygenated periods. The Fe fluxes at the deeper sampling locations away from the OMZ boundary are very low but more constant over time. This might explain that the $\mathrm{Fe} / \mathrm{Ca}$ ratios in B. spissa at the deepest sampling location is still in the same order of magnitude as in the surrounding pore waters while the discrepancy gets larger towards the central OMZ. These initial results show that the use of $\mathrm{Fe} / \mathrm{Ca}$ ratios in benthic foraminifera to reconstruct short time fluctuations in the oxygen supply at the Peruvian is a complex issue. Further studies should focus on the value of $\mathrm{Fe} / \mathrm{Ca}$ ratios in benthic foraminifera to reconstruct oxygen fluctuations over longer time scales.

\subsubsection{Variability of $\mathrm{Mn} / \mathrm{Ca}$ and $\mathrm{Fe} / \mathrm{Ca}$ in single $\mathrm{B}$. spissa specimens and a comparison between cleaned and uncleaned specimens and the analytical methods}

The $\mathrm{Mn} / \mathrm{Ca}$ and the $\mathrm{Fe} / \mathrm{Ca}$ ratios both obviously show a higher variability in tests of $B$. spissa from habitats with elevated $\left[\mathrm{O}_{2}\right]_{\mathrm{BW}}$. Infaunal foraminiferal species are able to migrate vertically in the sediments to where food availability and oxygenation meet their individual requirements (Jorissen et al., 1995; Duijnstee, 2003). At higher $\left[\mathrm{O}_{2}\right]_{\mathrm{BW}}$ and deeper oxygen penetration depth respectively $B$. spissa might be able to migrate deeper into the sediments. In this case individual specimens would be exposed to a wide range of $\mathrm{Mn}$ and $\mathrm{Fe}$ concentrations in the pore waters among their lifetime. The comparison between the cleaned and the uncleaned specimen from $640 \mathrm{~m}$ water depth (M77-1565/MUC-60) shows that the uncleaned specimen has an 
elevated $\mathrm{Fe} / \mathrm{Ca}$ and a slightly reduced $\mathrm{Mn} / \mathrm{Ca}$ ratio. The elevated $\mathrm{Fe} / \mathrm{Ca}$ ratio might originate from the contamination of that Fe rich phase which could be seen on EMP mappings of the uncleaned $B$. spissa and $U$. peregrina specimens. Nevertheless, both differences between the cleaned and the uncleaned specimen $\left(\mathrm{Mn} / \mathrm{Ca} \sim 1.88 \mu \mathrm{mol} \mathrm{mol}^{-1}\right.$; $\mathrm{Fe} / \mathrm{Ca} \sim 179.04 \mu \mathrm{mol} \mathrm{mol}^{-1}$ ) are in the same order of magnitude like the intra species variabilities at this site $(\mathrm{Mn} / \mathrm{Ca}$ $=1.20-3.38 \mu \mathrm{mol} \mathrm{mol}^{-1} ; \mathrm{Fe} / \mathrm{Ca}=115.4-242.8 \mu \mathrm{mol} \mathrm{mol}^{-1}$ ). Thus these differences might be more a variability in the lattice bound $\mathrm{Mn}$ and $\mathrm{Fe}$ concentrations between different specimens and not be connected to the cleaning protocols, since the SIMS analyses were done on clean areas inside the test walls where no pores were present. This might indicate that the cleaning protocol has no significant influence on the SIMS analyses when the spots on the test cross-sections are chosen with care. The comparison between the elemental ratios determined with SIMS and ICP-MS show that the difference between these methods is not higher than the intratest variability inside single specimens. This proves that SIMS is a valuable tool to determine precise elemental ratios even if they are very low like the $\mathrm{Mn} / \mathrm{Ca}$ ratios determined in this study. The possibility to determine the intratest variability could give further information about the environmental conditions in the habitat.

\section{Conclusions}

An iron rich phase has been found at the inner surface of the test walls and also in the pores of several specimens of $U$. peregrina. This phase also is enriched in $\mathrm{Al}, \mathrm{Si}, \mathrm{P}$ and $\mathrm{S}$ and it could be efficiently removed from the walls with an oxidative cleaning procedure. A similar phase enriched in $\mathrm{Fe}$ could be removed from the inner parts of the test walls of B. spissa with oxidative cleaning, too. Nevertheless, even after the oxidative cleaning Fe was still enriched in the pores. Thus an oxidative cleaning procedure is essential to minimize the influences of non-lattice bound signatures during the determination of element/Ca ratios even for some microanalytical methods. Furthermore it should be avoided to measure at parts of the test wall where pores are present. None of the EMP maps shows any hint for diagenetic coatings. Therefore a reductive cleaning for the determination of element/Ca ratios was not necessary. For minimisation of the whole procedure blank and the loss of sample material it is a good choice to avoid unnecessary cleaning steps.

First applications were done to measure $\mathrm{Mn} / \mathrm{Ca}$ and $\mathrm{Fe} / \mathrm{Ca}$ ratios with SIMS. A comparison of $\mathrm{Fe} / \mathrm{Ca}$ and $\mathrm{Mn} / \mathrm{Ca}$ ratios in tests of B. spissa determined with SIMS and ICPMS showed that the results of these two techniques agree in the order of magnitude as the variability inside single specimens determined with SIMS at these sampling sites. The low $\mathrm{Mn} / \mathrm{Ca}$ ratios are in the same magnitude as in the pore waters. The low Mn concentrations in the pore waters originate most propably from the strong oxygen depletion in the water column of the Peruvian OMZ. Most $\mathrm{MnO}_{2}$ is already reduced in the water column. The $\mathrm{Mn} / \mathrm{Ca}$ ratios in B. spissa correlate with the $\mathrm{Mn} / \mathrm{Ca}$ ratios in surrounding pore water. These first results show that $\mathrm{Mn} / \mathrm{Ca}$ ratios in benthic foraminifera from the Peruvian OMZ might be used to trace the amount of oxygen depletion in the OMZ. In downcore proxy application in the Peruvian OMZ higher $\mathrm{Mn} / \mathrm{Ca}$ ratios would most likely indicate a better oxygenation because more $\mathrm{MnO}_{2}$ settles down to the seafloor, being remobilised in the pore waters. The $\mathrm{Fe} / \mathrm{Ca}$ ratios in B. spissa are negatively correlated to the concentrations in the surrounding pore waters. Several observations at a strongly oxygen depleted location, like low $\mathrm{Fe} / \mathrm{Ca}$ ratios in B. spissa, a strong sharp Fe peak in the top interval of the pore water and the presence of a high amount of dead, but no living specimens of B. spissa, hint that this site just recently turned anoxic. Therefore the Fe flux out of the sediment started after the death of B. spissa at this site. The sharp peak also might hint that ironoxides, precipitated in a period of higher oxygen supply, just started to get remobilised when the sediment turned anoxic again.

The initial data presented in this study show that it is possible to measure $\mathrm{Mn} / \mathrm{Ca}$ and $\mathrm{Fe} / \mathrm{Ca}$ ratios by SIMS and ICP-MS in benthic foraminifera, even in low concentrations without significant influence of contaminants. The results also show that it might be difficult to reconstruct short time fluctuations in the oxygen supply to the Peruvian OMZ with $\mathrm{Fe} / \mathrm{Ca}$ ratios in B. spissa because they do not reflect always the pore water conditions. Basic problems for the pending calibration work are the fast changes in the Fe flux, because the monitoring cannot be assessed without living specimens. Also there can be a random quantity of unknown changes under lethal conditions which cannot be monitored at all. The $\mathrm{Mn} / \mathrm{Ca}$ ratios seem to be more promising because they directly reflect the pore water conditions. This work is to see as base for the still pending detailed calibration of the potential proxies. Future studies will show the value of these proxies in paleoreconstruction. 


\section{Appendix A}

Table A1. Spectrometer crystals used at the EMP for different elements.

\begin{tabular}{llllll}
\hline Element & Crystal & Element & Crystal & Element & Crystal \\
\hline $\mathrm{Ca}$ & PETJ & $\mathrm{Ba}$ & PETJ & $\mathrm{S}$ & PETH \\
$\mathrm{Mg}$ & TAPH & $\mathrm{Mn}$ & LIFH & $\mathrm{Si}$ & TAP \\
$\mathrm{Fe}$ & LIFH & $\mathrm{P}$ & PETH & $\mathrm{Al}$ & TAPH \\
\hline
\end{tabular}

Table A2. Operation conditions for Agilent 7500cx.

\begin{tabular}{|c|c|}
\hline & value/description \\
\hline RF power & $1500 \mathrm{~W}$ \\
\hline Nebulizer & $\begin{array}{l}\text { PFA }\left(100 \mu 1 \mathrm{~min}^{-1} \text {, }\right. \\
\text { self aspirating) }\end{array}$ \\
\hline Spray chamber & Glass (cooled to $2^{\circ} \mathrm{C}$ ) \\
\hline Autosampler & Cetac ASX 100 \\
\hline Uptake rate $\left(\mu 1 \min ^{-1}\right)$ & 100 \\
\hline Washout time (s) & 90 \\
\hline Uptake time (s) & 30 \\
\hline Argon plasma gas flow rate $\left(1 \mathrm{~min}^{-1}\right)$ & 15 \\
\hline Argon auxiliary gas flow rate $\left(1 \mathrm{~min}^{-1}\right)$ & $0.2-0.3$ \\
\hline Argon nebulizer gas flow rate $\left(1 \mathrm{~min}^{-1}\right)$ & $0.8-0.9$ \\
\hline Sample cone & Nickel (Agilent) \\
\hline Skimmer cone & Nickel \\
\hline $\mathrm{CeO} / \mathrm{Ce}$ and $\mathrm{Ba}^{2+} / \mathrm{Ba}^{+}$ratios & $<2.5 \%$ \\
\hline
\end{tabular}

Table A3. Element concentration for the different standard rows used for ICP-MS.

\begin{tabular}{llll}
\hline Standard & $\mathrm{Ca}(\mathrm{ppm})$ & $\mathrm{Fe}(\mathrm{ppt})$ & $\mathrm{Mn}(\mathrm{ppt})$ \\
\hline Row 1 std 1 & 10 & 150 & 5 \\
Row 1 std 2 & 10 & 250 & 10 \\
Row 1 std 3 & 10 & 500 & 15 \\
Row 1 std 4 & 10 & 1000 & 50 \\
Row 1 std 5 & 10 & 3000 & 100 \\
Row 1 std 6 & 10 & 5000 & 150 \\
Row 2 std 1 & 10 & 0 & 10000 \\
Row 2 std 2 & 10 & 0 & 20000 \\
Row 2 std 3 & 10 & 0 & 50000 \\
Row 2 std 4 & 10 & 0 & 75000 \\
Row 2 std 5 & 10 & 0 & 100000 \\
Row 3 std 1 & 10 & 0 & 0 \\
Row 3 std 2 & 50 & 0 & 0 \\
Row 3 std 3 & 100 & 0 & 0 \\
Row 3 std 4 & 200 & 0 & 0 \\
\hline
\end{tabular}
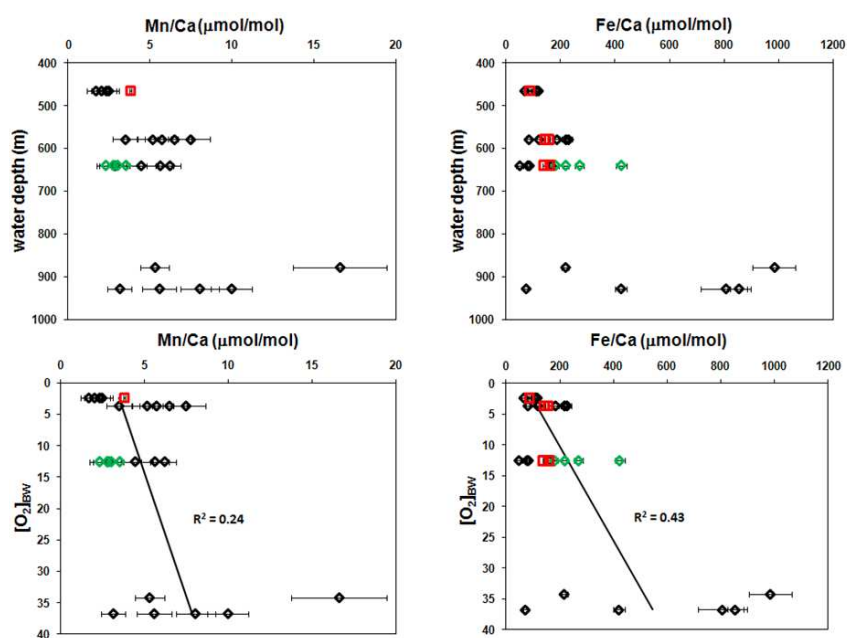

Fig. A2. $\mathrm{Mn} / \mathrm{Ca}$ and $\mathrm{Fe} / \mathrm{Ca}$ ratios in tests of Bolivina spissa plotted against water depth and $\left[\mathrm{O}_{2}\right]_{\mathrm{BW}}$. All data points are plotted. Red squares indicate data points measured on bulk samples of 40 specimens with ICP-MS while diamonds indicate values from specimens measured with SIMS. The specimens indicated by the black diamonds all have been treated with an oxidative cleaning procedure while the single green diamond represents an uncleaned specimen. Error bars show the analytical standard deviation of the method. 
Acknowledgements. We thank Anna Noffke, Florian Scholz, Bettina Domeyer, Meike Dibbern, and Renate Ebinghaus for performing pore-water trace element measurements, Mario Thöner for support in the operation of the EMP at GEOMAR in Kiel and Ilona Schäpan for support in the SIMS measurements at the GFZ in Potsdam. Ed Hathorne is acknowledged for providing of the OKA and ECRM 752 calibration standards to this work. The scientific party on R/V METEOR cruise M77 is acknowledged for their general support and advice in multicorer operation and sampling. The cleaning procedures were done in the clean lab of Dirk Nürnberg while Nadine Gehre always gave support when problems occurred in this lab. This work is a contribution of subproject B7 of the Sonderforschungsbereich 754 "Climate - Biogeochemistry Interactions in the Tropical Ocean" (www.sfb754.de) which is supported by the Deutsche Forschungsgemeinschaft. G. N. thanks the European Commission (grant 211384, EU FP7 "EPOCA"), and the German Federal Ministry of Education and Research (BMBF, FKZ 03F0608, "BIOACID") for financial support.

Edited by: J. Middelburg

\section{References}

Allison, N. and Austin, W. E. N.: The potential of ion microprobe analysis in detecting geochemical variations across individual foraminifera tests, Geochem. Geophys. Geosyst., 4, 8403, doi:10.1029/2002GC000430, 2003.

Baker, M. E., Ramirez-Liodra, K., and Perry, D.: ChEssBase: an online information system on biodiversity and biogeography of deep-sea chemosynthetic ecosystems, Version 3. World Wide Web electronic publications, http://www.noc.soton.ac.uk/chess/, 2010.

Barker, S., Greaves, M., and Elderfield, H.: A study of cleaning procedures used for foraminiferal $\mathrm{Mg} / \mathrm{Ca}$ paleothermometry, Geochem. Geophys. Geosyst., 4, 8407, 2003 doi:10.1029/2003GC000559, 2003.

Bé, A. W. H.: Shell Porosity of Recent Planktonik Foraminifera as a Climatic Index, Science, 161, 881-884, 1968.

Bender, M. L. and Heggie, D. T.: Fate of organic carbon reaching the deep sea floor: a status report, Geochim. Cosmochim. Acta, 48, 977-986, 1984.

Bernhard, J. M., Buck, K. R., and Barry, J. P.: Monterey Bay coldseep biota: Assemblages, abundance, and ultrastructure of living foraminifera, Deep-Sea Res. I, 48, 2233-2249, 2001.

Bertram, M. A. and Cowen, J. P.: Biomineralization in Agglutinating Foraminifera: An Analytical SEM Investigation of External Wall Composition in Three Small Test Forms, Aquat. Geochem., 4, 455-468, 1998.

Bertram, C. J., Elderfield, H., Shackleton, N. J., and MacDonald, J. A.: Cadmium/calcium and carbon isotope reconstructions of the glacial northeast Atlantic Ocean, Paleoceanography, 10, 563578, 1995.

Bice, K. L., Layne, G. D., and Dahl, K.: Application of secondary ion mass spectrometry to the determination of $\mathrm{Mg} / \mathrm{Ca}$ in rare, delicate, or altered planktonic foraminifera: Examples from the Holocene, Paleogene, and Cretaceous, Geochem. Geophys. Geosyst., 6, Q12P07, doi:10.1029/2005GC000974, 2005.

Boyle, E. A.: Cadmium, zinc, copper and barium in foraminifera tests, Earth Planet Sc. Lett., 53, 11-35, 1981.
Boyle, E. A.: Manganese carbonate overgrowths on foraminifera tests, Geochim. Cosmochim. Acta, 47, 1815-1819, 1983.

Boyle, E. A.: Cadmium: Chemical tracer of deep-water paleoceanography, Paleoceanography, 3, 471-489, 1988.

Boyle, E. A. and Keigwin, L. D.: Comparison of Atlantic and Pacific paleochemical records for the last 215,000 years: Changes in deep ocean circulation and chemical inventories, Earth Planet. Sci. Lett., 76, 135-150, 1985.

Burdige, D. J.: The biogeochemistry of manganese and iron reduction in marine sediments, Earth-Sci. Rev., 35, 249-284, 1993.

Came, R. E., Oppo, D. W., and Curry, W. B.: Atlantic Ocean circulation during the Younger Dryas: Insights from a new $\mathrm{Cd} / \mathrm{Ca}$ record from the western subtropical South Atlantic, Paleoceanography, 18, 1086, doi:10.1029/2003PA000888, 2003.

Delaney, M. L.: Miocene benthic foraminiferal $\mathrm{Cd} / \mathrm{Ca}$ records: South Atlantic and western Equatorial Pacific, Paleoceanography, 5, 743-760, 1990.

Eggins, S., De Deckker, P., and Marshall, J.: Mg/Ca variation in planktonic foraminifera tests: Implications for reconstructing paleoseawater temperature and habitat migration, Earth Planet. Sci. Lett., 6694, 1-16, 2003.

Eggins, S., Sadekov, A., and De Deckker, P.: Modulation and daily banding of $\mathrm{Mg} / \mathrm{Ca}$ in Orbulina universa tests by symbiont photosynthesis and respiration: A complication for seawater thermometry?, Earth Planet. Sci. Lett., 225, 411-419, 2004.

Elderfield, H. and Ganssen, G.: Past temperature and $\delta^{18} \mathrm{O}$ of surface ocean waters inferred from foraminiferal $\mathrm{Mg} / \mathrm{Ca}$ ratios, $\mathrm{Na}-$ ture, 405, 442-445, 2000.

Erez, J.: The source of ions for biomineralization in foraminifera and their implications for paleoceanographic proxies, in: Biomineralization: Mineralogical Society of America, edited by: Dove, P. M., De Yoreo, J. J., and Weiner, S., Washington DC, 115-149, 2003.

Erez, J., Levenson, Y., and Almogi-Labin, A.: Biomineralization and seawater dynamics in foraminifera studied with the fluorescent dye Calcein, Goldschmitt Conference Abstracts, p. 815, 2011.

Fhlaithearta, S. N., Reichart, G.-J., Jorissen, F. J., Fontanier, C., Rehling, E. J., Thomson, J., and De Lange, G. J.: Reconstructing the seafloor environment during sapropel formation using benthic foraminiferal trace metals, stable isotopes, and sediment composition, Paleoceanography, 25, PA4225, doi:10.1029/2009PA001869, 2010.

Foster, G. L.: Seawater $\mathrm{pH}, p \mathrm{CO}_{2}$ and $\left[\mathrm{CO}_{3}^{2-}\right]$ variations in the Caribbean Sea over the last 130 kyr: a boron isotope and $\mathrm{B} / \mathrm{Ca}$ study of planktic foraminifera, Earth Planet. Sc. Lett., 271, 254266, 2008.

Froelich, P. N., Klinkhammer, G. P., Bender, M. L., Luedtke, N. A., Heath, G. R., Cullen, D., Dauphin, P., Hammond, D., Hartman, B., and Maynard, V.: Early oxidation of organic matter in pelagic sediments of the eastern equatorial Atlantic: suboxic diagenesis, Geochim. Cosmochim. Acta, 43, 1075-1090, 1987.

Gaetani, G. A. and Cohen, A. L.: Element partitioning during precipitation of aragonite from seawater: A framework for understanding paleoproxies, Geochim. Cosmochim. Acta, 70, 41174137, 2006.

Gehlen, M., Bassinot, F., Beck, L., and Khodja, H.: Trace element cartography of Globigerinoides ruber shells using particleinduced X-ray emission, Geochem. Geophys. Geosyst., 5, 
Q12D12, doi:10.1029/2004GC000822, 2004.

Glock, N., Eisenhauer, A., Milker, Y., Liebetrau, V., Schönfeld, J., Mallon, J., Sommer, S., and Hensen, C.: Environmental influences on the pore-density in tests of Bolivina spissa, J. Foraminiferal Res., 41, 22-32, 2011.

Glud, R. N., Thamdrup, B., Stahl, H., Wenzhoefer, F., Glud, A., Nomaki, H., Oguri, K., Revsbech, N. P., and Kitazato, H.: Nitrogen cycling in a deep ocean margin sediment (Sagami Bay, Japan), Limnol. Oceanogr., 54, 723-734, 2009.

Goldstein, S. T. and Corliss, B. H.: Deposit feeding in selected deep-sea and shallow-water benthic foraminifera, DeepSea Res., 41, 229-241, 1994.

Gooday, A. J., Todo, Y., Uematsu, K., and Kitazato, H.: New organic- walled Foraminifera (Protista) from the ocean's deepest point, the Challenger Deep (western Pacific Ocean), Zool. Journ. of the Linn. Soc., 153, 399-423, 2008.

Granina, L., Müller, B., and Wehrli, B.: Origin and dynamics of Fe and Mn sedimentary layers in Lake Baikal, Chem. Geol., 205, 55-72, 2004.

Greaves, M., Caillon, N., Rebaubier, H., Bartoli, G., Bohaty, S., Cacho, I., Clarke, L., Cooper, M., Daunt, C., Delaney, M., deMenocal, P., Datton, A., and Eggins, S.: Interlaboratory comparison of calibration standards for foraminiferal $\mathrm{Mg} / \mathrm{Ca}$ thermometry, Geochem. Geophys. Geosyst., 9, Q08010, doi:10.1029/2008GC001974, 2008.

Gross, O.: Foraminifera, in: European register of marine species: a check-list of the marine species in Europe and a bibliography of guides to their identification, edited by: Costello, M. J., Emblow, C. S., and White, R., Collection Patrimoines Naturels, 50, 60-75, 2001.

Guitiérrez, D., Enríquez, E., Purca, S., Quipúzcoa, L., Marquina, R., Flores, G., and Graco, M.: Oxygenation episodes on the continental shelf of central Peru: Remote forcing and benthic ecosystem response, Prog. Oceanogr., 79, 177-189, 2008.

Haley, B. A. and Klinkhammer, G. P.: Development of a flowthrough system for cleaning and dissolving foraminiferal tests, Chem. Geol., 185, 51-69, 2002.

Haley, B. A., Klinkhammer, G. P., and Mix, A. C.: Revisiting the rare earth elements in foraminiferal tests, Earth Planet. Sc. Lett., 239, 79-97, 2005.

Hall, J. M. and Chan, L.-H.: Ba/Ca in Neogloboquadrina pachyderma as an indicator of deglacial meltwater discharge into the western Arctic Ocean, Paleoceanography, 19, PA4018, doi:10.1029/2004PA001028, 2004a.

Hall, J. M. and Chan, L.-H.: $\mathrm{Ba} / \mathrm{Ca}$ in benthic foraminifera: Thermocline and middepth circulation in the North Atlantic during the last glaciations, Paleoceanography, 19, PA1017, doi:10.1029/2003PA000910, 2004b.

Harding, D. J., Arden, J. W., and Rickaby, R. E. M.: A method for precise analysis of trace element/calcium ratios in carbonate samples using quadrupole inductively coupled plasma mass spectrometry, Geochem. Geophys. Geosyst., 7, Q06003, doi:10.1029/2005GC001093, 2006.

Hastings, D. W., Emerson, S., Erez, J., and Nelson, B. K.: Vanadium incorporation in foraminiferal calcite as a paleotracer for seawater vanadium concentrations, Geochim. Cosmochim. Acta, 19, 3701-3715, 1996a.

Hastings, D. W., Emerson, S. E., and Nelson, B.: Determination of picogram quantities of vanadium in foraminiferal calcite and seawater by isotope dilution inductively coupled plasma mass spectrometrwy ith electrothermavla porization, Anal. Chem., 68, 371-378, 1996b.

Hastings, D. W., Emerson, S. R., and Mix, A. C.: Vanadium in foraminiferal calcite as a tracer for changes in the areal extent of reducing sediments, Paleoceanography, 11, 665-678, 1996c.

Hastings, D. W., Russell, A. D., and Emerson, S. R.: Foraminiferal magnesium in Globeriginoides sacculifer as a paleotemperature proxy, Paleoceanography, 13, 161-169, 1998.

Hathorne, E. C., Alard, O., James, R. H., and Rogers, N. W.: Determination of intratest variability of trace elements in foraminifera by laser ablation inductively coupled plasmamass spectrometry, Geochem. Geophys. Geosyst., 4, 8408 , doi:10.1029/2003GC000539, 2003.

Heinz, P., Sommer, S., Pfannkuche, O., and Hemleben, C.: Living benthic foraminifera in sediments influenced by gas hydrates at the Cascadia convergent margin, NE Pacific, Mar. Ecol. Prog. Ser., 304, 77-89, 2005.

Heinz, P., Ruschmeier, W., and Hemleben, C.: Live benthic foraminiferal assemblages at the Pacific continental margin of Costa Rica and Nicaragua, Journal of Foraminiferal Research, 38, 215-227, 2008.

Kasemann, S. A., Schmitt, D. N., Bijma, J., and Foster, G. L.: In situ boron isotope analysis in marine carbonates and its application for foraminifera and palaeo-pH, Chemical Geology, 260, 138147, 2009.

Kunioka, D., Shirai, K., Takahata, N., Sano, Y., Toyofuku, T., and Ujiie, Y.: Microdistribution of $\mathrm{Mg} / \mathrm{Ca}, \mathrm{Sr} / \mathrm{Ca}$ and $\mathrm{Ba} / \mathrm{Ca}$ ratios in Pulleniatina obliquiloculata test by using NanoSIMS: implication for the vital effect mechanism, Geochem. Geophys. Geosyst., 7, Q12P20. doi:10.1029/2006GC001280, 2006.

Lea, D. W.: Trace elements in foraminiferal calcite Modern Foraminifera, edited by: Sen Gupta, B. K., Kluwer Academic Publishers, New York, Boston, Dordrecht, London, Moscow, 201-216, 2003.

Lea, D. W. and Boyle, E. A.: Barium content of benthic foraminifera controlled by bottom-water composition, Nature, 338, 751-753, 1989.

Lea, D. W. and Boyle, E. A.: Foraminiferal reconstruction of barium distributions in water masses of the glacial oceans, Paleoceanography, 5, 719-742, 1990a.

Lea, D. W. and Boyle, E. A.: A 210,000-year record of barium variability in the deep northwest Atlantic Ocean, Nature, 347, 269-272, 1990b.

Lea, D. W. and Boyle, E. A.: Barium in planktonic foraminifera, Geochim. Cosmochim. Acta, 55, 3321-3331, 1991.

Lea, D. W. and Spero, H. J.: Experimental determination of barium uptake in shells of the planktonic foraminifera Orbulina universa at $22^{\circ} \mathrm{C}$, Geochim. Cosmochim. Acta, 56, 2673-2680, 1992.

Lea, D. W. and Spero, H. J.: Assessing the reliability of paleochemical tracers: Barium uptake in the shells of planktonic foraminifera, Paleoceanography, 9, 445-452, 1994.

Lea, D. W., Mashiotta, T. A. and Spero, H. J.: Controls on magnesium and strontium uptake in planktonic foraminifera determined by live culturing, Geochim. Cosmochim. Acta, 63, 2369-2379, 1999.

Lear, C. H., Rosenthal, Y., and Slowey, N.: Benthic foraminiferal $\mathrm{Mg} / \mathrm{Ca}$-paleothermometry: A revised coretop calibration, Geochim. Cosmochim. Acta, 66, 3375-3387, 2002. 
Levin, L. A., Gutiérrez, D., Rathburn, A., Neira, C., Sellanes, J., Munoz, P., Gallardo, V., and Salamanca, M.: Benthic processes on the Peru margin: a transect across the oxygen minimum zone during the 1997-1998 El-Nino, Prog. Oceanogr., 53, 1-27, 2002.

Lutze, G. F.: Variiationsstatistik und Ökologie bei rezenten Foraminiferen: Paläontologische Zeitschrift, 36, 252-264, 1962.

Mallon, J., Glock, N. and Schönfeld, J.: The response of benthic foraminifera to low-oxygen conditions of the Peruvian oxygen minimum zone, in: ANOXIA: Evidence for eukaryote survival and paleontological strategies, Cellular Origin, Life in Extreme Habitats and Astrobiology 21, edited by: Altenbach, A. V., Bernhard, J. M., and Seckbach, J., Springer Science+Business Media, 305-321, doi:10.1007/978-94-007-1896-8_16, 2011.

Marchitto Jr., T. M., Curry, W. B., and Oppo, D. W.: Zinc concentrations in benthic foraminifera reflect seawater chemistry, Paleoceanography, 15, 299-306, 2000.

Marchitto, T. M.: Precise multielemental ratios in small foraminiferal samples determined by sector field ICP-MS, Geochem. Geophys. Geosyst., 7, Q05P13, doi:10.1029/2005GC001018, 2006.

Martin, P. A. and Lea, D. W.: Comparison of water mass changes in the deep tropical Atlantic derived from $\mathrm{Cd} / \mathrm{Ca}$ and carbon isotope records: Implications for changing Ba composition of deep Atlantic water masses, Paleoceanography, 13, 572-585, 1998.

Mosch, T., Sommer, S., Dengler, M., Noffke, A., Bohlen, L., Pfannkuche, O., and Wallmann, K.: Structuring forces on epibenthic communities across the Peruvian oxygen minimum zone, Deap Sea Res., in review, 2012.

Munsel, D., Kramar, U., Dissard, D., Nehrke, G., Berner, Z., Bijma, J., Reichart, G.-J., and Neumann, T.: Heavy metal incorporation in foraminiferal calcite: results from multi-element enrichment culture experiments with Ammonia tepida, Biogeosciences, 7, 2339-2350, doi:10.5194/bg-7-2339-2010, 2010.

Ni, Y., Foster, G. L., Bailey, T., Elliott, T., Schmidt, D. N., Pearson, P., Haley, B., and Coath, C.: A core top assessment of proxies for the ocean carbonate system in surface dwelling Foraminifers, Paleoceanography, 22, PA3212, doi:10.1029/2006PA001337, 2007.

Nomaki, H., Heinz, P., Nakatsuka, T., Shimanaga, M., Ohkouchi, N., Ogawa, N. O., Kogure, K., Ikemoto, E., and Kitazato, H.: Different ingestion patterns of ${ }^{13} \mathrm{C}$-labeled bacteria and algae by deep-sea benthic foraminifera, Mar. Ecol. Prog. Ser., 310, 95108, 2006.

Nürnberg, D.: Magnesium in tests of Neogloboquadrina pachyderma sinistral from high northern and southern latitudes, J. Foraminiferal Res., 25, 350-368, 1995.

Nürnberg, D., Bijma, J., and Hemleben, C.: Assessing the reliability of magnesium in foraminiferal calcite as a proxy for water mass temperatures, Geochim. Cosmochim. Acta, 60, 803-814, 1996.

Ohkouchi, N., Kawahata, H., Murayama, M., Ohkada, M., Nakamura, T., and Taira, A.: Was deep water formed in the North Pacific during the Late Quaternary? Cadmium evidence from the northwest Pacific, Earth Planet. Sc. Lett., 124, 185-194, 1994.

Pakhomova, S. V., Hall, P. O. J., Kononets, M. Y., Rozanov, A. G., Tengberg, A., and Vershinin, A. V.: Fluxes of iron and manganese across the sediment-water interface under various redox conditions, Mar. Chem., 107, 319-331, 2007.

Palmer, M. R., Pearson, P. N., and Cobb, S. J.: Reconstructing past ocean pH-depth profiles, Science 282, 1468-1471, 1998.
Palmer, M. R. and Pearson, P. N.: A 23,000-year record of surface water $\mathrm{pH}$ and $p \mathrm{CO}_{2}$ in the western equatorial Pacific Ocean, Science 300, 480-482, 2003.

Pearson, P. N. and Palmer, M. R.: Atmospheric carbon dioxide concentrations over the past 60 million years, Nature, 406, 695-699, 2000.

Pedersen, T. F., Pickering, M., Vogel, J. S., Southon, J. N., and Nelson, D. E.: The response of benthic foraminifera to productivity cycles in the eastern equatorial Pacific: Faunal and geochemical constraints on glacial bottom water oxygen levels, Paleoceanography, 3, 157-168, 1988.

Pena, L. D., Calvo, E., Cacho, I., Eggins, S., and Pelejero, C.: Identification and removal of $\mathrm{Mn}-\mathrm{Mg}$-rich contaminant phases on foraminiferal tests: Implications for $\mathrm{Mg} / \mathrm{Ca}$ past temperature reconstructions, Geochem. Geophys. Geosyst., 6, Q09P02, doi:10.1029/2005GC000930, 2005.

Pena, L. D., Cacho, I., Calvo, E., Pelejero, C., Eggins, S., and Sadekov, A.: Characterization of contaminant phases in foraminifera carbonates by electron microprobe mapping, Geochem. Geophys. Geosyst., 9, Q07012, doi:10.1029/2008GC002018, 2007.

Rae, J. W. B., Foster, G. L., Schmitt, D. N., and Elliot, T.: Boron isotopes and $\mathrm{B} / \mathrm{Ca}$ in benthic foraminifera: Proxies for the deep ocean carbonate system, Earth Planet. Sc. Lett., 302, 403-413, 2011.

Reichart, G.-J., Jorissen, Mason, F. P. R. D., and Anschutz, P.: Single foraminiferal test chemistry records the marine environment, Geology, 31, 355-358, 2003.

Rollion-Bard, C. and Erez, J.: Intra-shell boron isotope ratios in the symbiont-bearing benthic foraminiferan Amphistegina lobifera: Implications for $\delta^{11} \mathrm{~B}$ vital effects and paleo-pH reconstructions, Geochim. Cosmochim. Acta, 74, 1530-1536, 2010.

Rollion-Bard C., Erez J., and Zilberman T.: Intra-shell oxygen isotope ratios in the benthic genus Amphistegina and the influence of seawater carbonate chemistry and temperature on this ratio, Geochim. Cosmochim. Acta, 72, 6006-6014, 2008.

Rosenthal, Y., Boyle, E. A., and Slowey, N.: Temperature control on the incorporation of magnesium, strontium, fluorine, and cadmium into benthic foraminiferal shells from Little Bahama Bank: Prospects for thermocline paleoceanography, Geochim. Cosmochim. Acta, 61, 3633-3643, 1997.

Russell, A. D., Emerson, S., Nelson, B., Erez, J., and Lea, D. W.: Uranium in foraminiferal calcite as a recorder of seawater uranium concentrations, Geochim. Cosmochim. Acta, 58, 671-681, 1994.

Russell, A. D., Hönisch, B., Spero, H. J., and Lea, D. W.: Effects of seawater carbonate ion concentration and temperature on shell $\mathrm{U}$, $\mathrm{Mg}$, and $\mathrm{Sr}$ in cultured planktonic foraminifera, Geochim. Cosmochim. Acta, 68, 4347-4361, 2004.

Sadekov, A. Y., Eggins, S. M., and De Deckker, P.: Characterization of $\mathrm{Mg} / \mathrm{Ca}$ distributions in planktonic foraminifera species by electron microprobe mapping, Geochem. Geophys. Geosyst., 6, Q12P06, doi:10.1029/2005GC000973, 2005.

Sano, Y., Shirai, K., Takahata, N., Hirata, T., and Sturchio, N. C.: Nano-SIMS analysis of $\mathrm{Mg}, \mathrm{Sr}, \mathrm{Ba}, \mathrm{U}$ in natural calcium carbonate, Anal. Sci., 21, 1091-1097, 2005.

Sanyal, A., Hemming, N. G., Hanson, G. N., and Broecker, W.: Evidence for a higher $\mathrm{pH}$ in the glacial ocean from boron isotopes in foraminifera, Nature, 373, 234-236, 1995. 
Sanyal, A., Bijma, J., Spero, H. J., and Lea, D.: Empirical relationship between $\mathrm{pH}$ and the boron isotopic composition of Globigerinoides sacculifer: implications for the boron isotope paleopH proxy, Paleoceanography, 16, 515-519, 2001.

Scholz, F., Hensen, C., Noffke, A., Rhode, A., and Wallmann, K.: Early diagenesis of redox-sensitive trace metals in the Peru upwelling area - response to ENSO-related oxygen fluctuations in the water column, Geochim. Cosmochim. Acta, 22, 7247-7276, 2011.

Sen Gupta, B. K., Smith, L. E., and Machain-Castillo, M. L.: Foraminifera of the Gulf of Mexico, in: Gulf of Mexico - Origins, Waters, and Biota, Biodiversity, edited by: Felder D. L. and Camp, D. K., Texas A\&M Press, College Station, Texas, 87-129, 2009.

Silva, K. A., Corliss, B. H., Rathburn, A. E., and Thunell, R. C.: Seasonality of living benthic foraminifera from the San Pedro Basin, California Borderland, Journal of Foraminiferal Research, 26, 71-93, 1996.

Sliter, W. V.: Test ultrastructure of some living benthic foraminifers: Lethaia, 7, 5-16, 1974.

Spivack, A. J., You, C.-F., and Smith, H. J.: Foraminiferal boron isotope ratios as a proxy for surface ocean $\mathrm{pH}$ over the past 21 Myr, Nature, 363, 149-151, 1993.

Strub, T., Mesías, J., Montecino, V., Rutllant, J., and Salinas, S.: Coastal ocean circulation off western South America, in: The Sea, edited by: Robinson, A. and Brink, K., vol. 11. New York: John Wiley and Sons, Inc., 29-67, 1998.
Suits, N. S. and Arthur, M. A.: Sulfur diagenesis and partitioning in Holocene Peru shelf and upper slope sediments, Chem. Geol., 163, 219-234, 2000.

Toyofuku, T. and Kitazato, H.: Micromapping of $\mathrm{Mg} / \mathrm{Ca}$ values in cultured specimens of the high-magnesium benthic foraminifera, Geochem. Geophys. Geosyst., 6, Q11P05, doi:10.1029/2005GC000961, 2005.

Wu, G. and Hillaire-Marcel, C.: Application of LP-ICP-MS to benthic foraminifers, Geochim. Cosmochim. Acta, 59, 409-414, doi:10.1016/0016-7037(94)00370-2, 1995.

Yu, J., Day, J., Greaves, M., and Elderfield, H.: Determination of multiple element/calcium ratios in foraminiferal calcite by quadrupole ICP-MS, Geochem. Geophys. Geosyst., 6, Q08P01, doi:10.1029/2005GC000964, 2005.

Yu, J., Elderfield, H., Greaves, M., and Day, J.: Preferential dissolution of benthic foraminiferal calcite during laboratory reductive cleaning, Geochem. Geophys. Geosyst., 8, 17, doi:10.1029/2006GC001571, 2007.

Yu, J., Elderfield, H., Jin, Z., and Booth, L.: A strong temperature effect on U/Ca in planktonic foraminiferal carbonates, Geochim. Cosmochim. Acta, 72, 4988-5000, 2008. 